\title{
Bank market power and SME finance: firm-bank evidence from European countries
}

Article

Accepted Version

Creative Commons: Attribution-Noncommercial-No Derivative Works 4.0

Wang, X., Han, L. and Huang, X. (2020) Bank market power and SME finance: firm-bank evidence from European countries. Journal of International Financial Markets, Institutions and Money, 64. 101162. ISSN 1042-4431 doi: https://doi.org/10.1016/j.intfin.2019.101162 Available at https://centaur.reading.ac.uk/88097/

It is advisable to refer to the publisher's version if you intend to cite from the work. See Guidance on citing.

To link to this article DOI: http://dx.doi.org/10.1016/j.intfin.2019.101162

Publisher: Elsevier

All outputs in CentAUR are protected by Intellectual Property Rights law, including copyright law. Copyright and IPR is retained by the creators or other copyright holders. Terms and conditions for use of this material are defined in the End User Agreement.

www.reading.ac.uk/centaur

\section{CentAUR}


Central Archive at the University of Reading

Reading's research outputs online 


\title{
Bank market power and SME finance: firm-bank evidence from European countries
}

\begin{abstract}
Using unique matched data on SME-bank relationships from 19 European countries, we examine the effects of bank-level market power on SME finance. We show novel evidence that bank market power at disaggregate level reduces SMEs' access to bank finance and worsens their credit constraints. Whilst, banking market concentration improves credit supply to SMEs. The unfavourable market power effect is stronger for SMEs who are more informationally opaque, riskier and more dependent on external finance. We also show supporting evidence on Information-based Hypothesis where with greater market power, banks are more likely to engage in relationship lending.
\end{abstract}

Key words: SME, bank relationship, market power, financing constraint JEL: G10, G21, M21

Acknowledgement: We thank Prof Batten and two anonymous referees for their valuable and insightful comments, which have hugely improved the paper. 


\section{Introduction}

Unlike many other industries, financial institutions play various roles and multiple functions in an economy. For example, banks are the implementers of a sovereign's monetary policies, for-profit organisations, and also the intermediations which provide credit and liquidity, risk reduction and maturity transformation processes to the markets. Of these unique roles, studies have garnered increasing interest in the banking effects on microeconomic agents.

The debate on the effects of bank competition or bank market power on the credit supply to small and medium-sized enterprises (SMEs) is far from settled. Conventional competition models suggest that market power has an unfavourable effect on customers in many ways but due to the special role of information, market power of banks may have dubious effects than other industries on their customers. European SMEs are ideal for the study because of their scales in the European Economic Area (EEA) countries and bank finance is still the dominant source of financing amongst others (Siedschlag, 2014). Also, prior studies have shown that SME's access to finance is a crucial determinant of its ability to survive and develop, and it aggregately affects a country's economic stability and growth. For example, SME's financing fulfilment is a crucial determinant of launching new products and improving knowledge transfer (Ayyagari et al., 2011) and SME's access to finance is a key to achieve higher employment growth (Campello and Larrain, 2014).

Empirical evidence has not consistently concluded the impacts of bank market power on SME credit availability because of the mixture of theoretical conjectures, different samples used and distinct interpretations of bank market power, in existing literature. In this paper, we investigate for the first time in literature how bank market power at disaggregate level affects the financing constraints of SMEs in 19 European countries (18 EU member states and Iceland) by adopting a unique matched firm-bank database.

Our main findings suggest that bank market power at disaggregate level impedes SMEs' access to finance, worsens their credit constraint, and bank competition promotes credit supply to SMEs if the results are translated into country level. The unfavourable market power effect is stronger for SMEs which are more informationally opaque, riskier and more dependent on external finance. Although, SME credit constraint is alleviated in the banking markets which are more concentrated, such an effect is more favourable in explaining firm's probability of obtaining finance but less economically significant in explaining the usage of bank debt. Our results show supporting evidence to the Market Power Hypothesis (MPH) where lower competition increases financial constraints but reject the validity of the Structure-Conduct-Performance paradigm (SCP). We also show supporting evidence on the Information-based Hypothesis (IBH) where with a greater market power, banks are more likely to engage in relationship lending as shown by more long-term lending between bank and SMEs, suggesting that two competing banking theories are coexistent. Our findings are robust to several econometric tests, especially the endogeneity concerns. On one hand, one might argue that there could exist unobservable factors either at macroeconomic, bank, or firm-level that could affect both bank 
market power (and/or control variables) and SME finance. On the other, there could be a contemporaneous reverse causality concern in our equations, where an SME's access to finance or bank debt ratio might determine the market level of its bank creditor or other control variables included in the equations. To empirically address these endogeneity concerns and further validate our findings, we perform robustness tests by using lagged explanatory variable, and employing instrumental variable estimations and Generalised Method of Moments estimations for a dynamic specification with endogeneity corrections on both dynamic and static variables, for example. Our results are robust to a wide range of such tests.

Our research contributes to the existing literature in several ways. First, we make a distinction between bank market power and bank concentration effects on SMEs by accounting for the fact that banking market concentration is an inappropriate measure of bank market power (e.g. Bolt and Humphrey, 2015). Second, our unique matched data employed allows us to test the direct and heterogenous effects of market power at bank-level on SMEs in a country at a disaggregate level, where the country-level measures are widely criticised previously (e.g. Ergungor, 2004; Ratti et al., 2008). Third, we provide more intuitive and objective empirical evidence in relevant research areas by using objective indicators of SMEs' bank credit usage rather than indirect proxies such as the sensitivity of SME performance on bank debt usage (e.g. Agostino and Trivieri, 2010), cash-investment sensitivity (e.g. Ryan et al. 2014), and subjective self-assessed financial obstacle measures (e.g. Beck et al. 2004). Fourth, unlike Love and Peria (2014) and Mudd (2013), our study examines not only the probability of access to finance but also the quantity associated to address the credit rationing of SMEs. Fifth, different from most previous studies (e.g. Ryan et al. 2014) that only adopt country-level bank market power or concentration measures with an assumption of exogeneity, we use unique matched bank-SME data and address the endogeneity concerns in several ways to enhance the validity of results. Additionally, we present several tests that account for different industry-level inherent financing habits, and examine the bank market power effects on bank loan structure in terms of maturity. Last, our study employs a rich cross-country panel containing nearly 80,000 firms, much representative than most of the existing literature (e.g. Love and Peria, 2014; Leon, 2015). Benefit from financial reporting data and crosscountry nature, this rich sample allows us to comprehensively control for SME credit supply heterogeneities, SMEs' credit demand and financing capability. To our knowledge, this is the first empirical study using matched firm-bank microeconomic-level data to examine the effects of bank market power on SME financing constraints and debt usage in a cross-country setting, and to assess the roles of information opaqueness and debt dependency on moderating the bank market power effects. Our study also contributes to the literature by empirically showing that the two competing theories (MPH and IBH) actually coexist in a practical European context.

The paper proceeds as follows. The next section presents a brief summary of relevant empirical literature and theories. Section 3 illustrates the data and research methodology. Section 4 presents the results. The last section concludes the paper and discusses the policy implications. 


\section{Literature Review}

\subsection{Bank market power and SME finance}

In the pace of globally springing up of SME surveys available in recent years, studies have started to match them with other banking market databases. Using the World Bank Enterprises Survey (WBES) data spanning unevenly from 2002 to 2010, Love and Peria (2014) adopt non-structural bank competition measures and show that the low level of competition diminishes SMEs' access to finance while the structural measures are not significant predictors. Another study by Mudd (2013), which employs a smaller fraction of the WBES containing a sample of one-off 33 countries, draws similar conclusions for both structural and non-structural measures. Both studies capture the financing condition of an SME by a binary variable that is equal to one if an SME has access to finance. Beck et al. (2004) measure SME financing obstacles at micro-level by directly asking the level of problematicness of financing for the operation and growth of the business. A 74-country international study (WBES) supports the Structure-Conduct-Performance paradigm (SCP) that bank market concentration increases SMEs' obstacles to obtaining finance in the countries with low level of economic and institutional development. However, the validity of the concentration measure is questionable because smaller countries in their studies in nature have higher concentration ratio than large countries due to the inconsistent size of economies (e.g. Belize vs. France). Using a recent wave of WBES covering 69 developing and emerging countries, Leon (2015) advances Beck et al.'s (2004) study by classifying credit constraints into self-discouragement and application rejection. They show that in developing countries, SME financing constraints, in the senses of reduced lending standards and discouragement, declined in countries where banking markets are more competitive and such results are only valid when non-structural measures are used but not valid for concentration measures. Han et al. (2009) produce similar findings using a large U.S. dataset that low risk borrowers are less likely to be self-discouraged in less competitive banking markets. Rice and Strahan (2010) adopt the same database as Han et al. (2009) in the U.S. and show that in states with more competition, small firms depend more heavily on bank finance and are associated with lower level of credit constraints.

For some non-U.S. single country studies, Chong et al. (2013) find that joint-stock banks (less market power) have higher credit supply to SMEs compared with stated-owned or city commercial banks (more market power). Similar conclusion is made in Italy (Agostino and Trivieri, 2010) by using financial reporting data instead of surveys. Also using financial statement data, Ryan et al. (2014) apply a panel data of 118,000 firms. By altering Fazzari et al.'s (1988) cash-investment sensitivity model, they show that Lerner Index has a positive effect on SMEs investment, and the sensitivity of dependence of investment on internal financing is stronger in less competitive banking markets.

Above studies in general support the conjecture that bank competition improves credit availability of SMEs. Firms perceive or experience higher levels of financing constraints, e.g. lack of 
access to finance, application rejection, discouragement, credit rationing and relatively high dependence on internal funds for investment, in less competitive banking markets, supporting the SCP Hypothesis or the Market Power Hypothesis.

Another set of studies emphases on the unfavourable effects of bank competition on SME credit supply. Ratti et al. (2008) adopt the cash-investment sensitivity model and show that in 14 European countries, increased concentration as a proxy of decreased competition in the banking sector relaxes SMEs' dependence on internal fund for investment. Alvarez and Bertin (2016) show that bank competition, proxied by national level Boone Indicator (Boone, 2008), reduces credit supply to meeting SME credit demand, and the impact is greater for SMEs that are smaller or lower in tangibility in a sample comprising of six Latin America countries. This result is consistent with the information-based Hypothesis; but the usage of Boone indicator at country level may not be ideal since unlike Europe, countries such as Brazil and Mexico in their sample are relatively large where regional bank competition disparities can be significant.

Study by Zarutskie (2006) is also in favour of the Information-based Hypothesis, showing that increased competition of the U.S. banking markets through a Branching Act that encourages interstate banking activities led to newly formed SMEs experiencing higher level of financing constraints with less access to external debt. Two other recent single-country studies, Abubakr and Esposito (2012) and Tacneng (2014) support the Information-based Hypothesis as well in the UK and Philippine. In addition, Baert and Vennet (2008) report that banking market concentration expands firms' access to long-term debt because relationship banking serves to mitigate information asymmetries and to reduce agency cost in a rich sample containing 12,049 firms from 39 mostly advanced countries.

All these studies have evidenced that bank market power promotes credit availability for SMEs, where financing constraints identified in these studies are defined as a greater sensitivity of investment to internal funds or a low level of debt usage. However, due to the reason of the shortage of loan level data in non-survey-based studies, financial constraints such as self-assessment on constraint level, discouragement or application rejection are not observable. Although these two camps of studies which provide contrasting conclusions, some suggest that the relation does not necessarily qualify for linearity (e.g. Di Patti and Dell'Ariccia, 2004; Cetorelli and Gambera, 2011) or two contrasting hypotheses could coexist (e.g. Han et al., 2017). Carbo-Valverde et al. (2009), for example, show that market power is negatively related to credit availability only when the Lerner Index is used but concentration ratio presents opposite conclusion.

\subsection{Relevant theories}

Due to the facts that SMEs have lack of formal financial and audit information, credit history, and low information disclosure requirements, they are more informationally opaque than many other types of borrowers (e.g. large firms). Hence, banks face more information asymmetries when identifying their credibility (Griffins, 2002). SMEs are also more likely to be credit rationed in loan markets with 
imperfect information when creditors (banks) have problems in differentiating between borrower's credit risk level, and because of their limited liability subject to loan default as well especially when they are less capable of providing collaterals (Ghosh et al., 1999). Banks consume multi-resources to reduce the possibility of loan impairments, but SMEs are low in transparency, resulting in high screening and monitoring costs for banks, and therefore lending activities face a greater degree of uncertainties. Furthermore, Holmstrom and Tirole (1998) state that the moral hazard dilemma is an expost behaviour happening when entrepreneurs intentionally act differently after the contract being issued by exerting and exercising deviated effort and risk-level. Borrowers, especially SMEs, are incentivised to behave in a speculative manner because the profit functions between borrowers and creditors are different. Borrower's expected return is an increasing function against risk level but bank's expected return is a decreasing function on project risk. This dilemma can be alleviated when the borrower does not deliberately deviate from the original proposals (e.g. high reputation, better investment information disclosure), when the after-contract activities can be properly monitored and when the collaterals can provide high guaranties to banks. However, all of these do not always fit under the context of SME lending.

Above mentioned literature has suggested that SME lending activities involve significant risk (especially credit risk) and therefore positively associated with the risk-level that banks taking on. Empirically, Carbo-Valverde et al. (2009) have proven that when banks taking on more credit risk, reference SMEs' credit constraints relaxed. However, evidence on the impact of bank market power on bank risk-taking (including credit risk) are also fairly mixed. The competition-stability hypothesis (CSH) indicates that an increase (decrease) in bank market power leads to banks taking more (less) risk and hence involving more in high risk activities including SME lending; while, the competition-fragility hypothesis $(\mathrm{CFH})$ suggests the opposite direction. Both hypotheses have a wide range of supporting evidence; empirically, Leroy and Lucotte (2017), Soedarmono et al. (2013), Fiordelisi and Mare (2014) and Akins et al. (2016) support the CSH, and Forssbeck and Shehzad (2016), Jimenez et al. (2007) and Agoraki et al. (2011) support the CFH. There are also studies (Lapteacru, 2017 and Fu et al., 2014) suggesting the co-existence of two hypotheses, and Kick and Prieto (2015) show that market power has no impact on bank risk-taking level.

Ruckes (2004) proposes a 'competition - credit standard hypothesis' that could also explain the relation between bank market power and SME credit availability, suggesting that improved (worsen) economic outlook leads to creditors competing fiercer (lesser) over price (market power) and reduced (increased) borrowers' default probability. Thus, lending standards are softened (strengthened) accordingly, resulting in firms with higher risk or lower capability of accessing to finance being granted bank finance easier or cheaper (harder or more expensive). Demiroglu et al. (2012) extend Ruckes' hypothesis by considering the effect to a more specific group of firms. They show that the effect of tighter lending standards is associated with a higher margin of decline in private firms' access to finance compared to public firms, and private firms are significantly less likely to access to new lines of bank 
credit when banks are tightening lending standards than are public firms, suggesting that tighter lending standards are associated with banks being more selective in credit supply to less transparent firms such as SMEs.

Boyd and De Nicolo (BDN, 2005) propose a contrasting conjecture based on the assumption that banks' lending market power is a result of their technology advantage on loan screening and monitoring. Banks with relative technology disadvantage spend more and consume longer period on screening loan applications; costs are therefore transferred to borrowers as a result of incurring financing obstacles although these banks may wish to mitigate this disadvantage by taking more risk such as alleviating lending standards and reducing expenses on monitoring and screening to prevent from market share reduction. While, banks with lending technology advantage have more discourse power over the lending market, and they shift their cost efficiency to credit worthy clients by reducing interest or non-interest costs in order to keep increasing their market shares for long-term prosperity. Hence, such a conjecture implies that bank market power resulted from technology advantage would be positively related to the amount of credit available to creditworthy borrower such as those with better credit rating scores.

Furthermore, there are two most widely acknowledged, albeit contrasting hypotheses in literature, the Market Power Hypothesis (MPH) and the Information-based Hypothesis (IBH), on the effect bank market power on SME's access to credit. The MPH conjectures that, under the conventional industrial organisation theory, market power enables firms to engage in anticompetitive behaviours (e.g. Vatiero, 2010). Under the banking context, market power could result in restricted loan supply, selective avoidance and manipulated lending rates, thereby intensifying borrowers' financing constraints. It is worth noting that the Structure-Conduct-Performance paradigm (SCP) illustrates similar results as the MPH, but it hypothesises that market structure influences bank conducts and therefore influences bank performance. Leading banks' profitability increase when the market is highly concentrated because of the collusion behaviour and thus results in higher oligopoly rents and higher credit constraints to borrowers (Bikker and Bos, 2008). However, the SCP defines the market power of a banking market by the structure or assets concentration level of the market, as pointed out by Carbo-Valverde et al. (2009) that the theoretical framework of the SCP derived from oligopoly theory only holds in a Cournot setting but not robust in alternative settings (Lau, 1982) and for banking industry where existing studies have widely rejected the assumption of Cournot conducts (e.g. Berg and Kim, 1994). Moreover, Berger (1995) suggests that the empirical findings of the SCP might not be persuasive since the positive relationship between concentration and monopoly profit could be biased due to its high correlation with other variables. The independence of bank market power from banking market concentration has also been empirically proved by Lapteacru (2014) and Bolt and Humphrey (2015). For all these reasons, we disentangle bank-level market power effect from country-level banking market concentration. Although it is not the main purpose of this study, we still examine if concentration improves SMEs access to credit. The idea is that it could be easier for governing authorities to supervise and regulate banks' 
activities in a banking market that is highly concentrated, therefore preventing them from anticompetitive behaviour, alleviating information asymmetries between creditors and borrowers, in order to promote credit supply to SMEs, known as 'Easy-supervision Hypothesis'. Gonzalez and Gonzalez (2008) provide evidence that firm's external finance usage is increased with greater bank concentration, and concentration benefits for better creditor protection to reduce the agency cost of debt between shareholders and debt holders.

In contrast to MPH, IBH (Petersen and Rajan, 1995) conjectures that in the presence of information asymmetries and agency costs, market power incentivises banks to invest in soft or private information acquisition and to build lending relationships that reduce the information asymmetries and agency costs between lenders and borrowers, and thereby allows banks to efficiently internalise the costs of collecting such information, to extract informational rents in subsequent periods and to promote access to finance especially for informationally opaque firms such as SMEs. In addition, Ergungor (2004) extends the study of Boot and Thakor (2000) and proposes a view that bank's lending techniques are either relationship-based or transaction-based. In a more competitive banking market, bank's profitability is reduced from both lending techniques but the negative effect is stronger for transaction lending, and thus banks are encouraged to shift to relationship lending, resulting in reduced SME financing constraints.

We have so far reviewed some representative relevant studies, discovered very inconsistent empirical results and analysed the theoretical reasons behind. Our study distinguishes the effects between disaggregate level bank market power and macroeconomic level concentration and examines how bank market power at microeconomic level affects SME's access to finance, debt usage and capital structure and what hypothesis the evidence reflects. We also test if the impacts of bank market power vary across different firm, banking market and macroeconomic heterogeneities.

\section{Data, Variables, and Model Specification}

\subsection{Data source and matching}

To overcome the weaknesses of many SME survey data, such as low response rates (e.g. SME Finance Monitor), small sample size (e.g. Cambridge Centre for Business Research) and cross-sectional nature (e.g. Small Business Survey), we collect firm information from BvD Amadeus database in which 99\% of the samples are private firms. Due to the low quality of SME accounting information in the full Amadeus subscription (e.g. non-genuine values), we use the sub-subscription of Amadeus. SMEs are defined as those firms which have less than 250 employees and less than $€ 50$ million turnover ${ }^{1}$ (European Commission).

\footnotetext{
${ }^{1}$ Estimation is used when such information is not available by running basic regressions and multipliers amongst turnovers, total assets and employees by two-digit NACE1 and UK SIC 07 industry code. We also exclude sample firms which do not meet the criteria in some particular ways by screening the samples on their accounting
} 
We collect bank level accounting data from Fitch Connect and bank specialisation data from Orbis Bankscope (now BankFocus). Bank accounting data can be directly matched with firm data but market power variables need full bank data to generate, including those which do not have relationships with the SMEs in this sample ${ }^{2}$. To control for different economic and time-series heterogeneities, we collect macro-economic and banking market data from The World Bank, interest rate data from European Commission (AMECO) and Eurostat and other data from European Central Bank (ECB) Datawarehouse and The Heritage Foundation Index. Data are matched between firm and bank through country code and year.

We follow existing literature (Kalemli-Ozcan et al., 2019; Marco, 2019; Barbiero et al., 2016; Ferrando et al., 2015; Ongena et al., 2015; Vigneron et al., 2016; Ongena and Sendeniz-Yuncu, 2011 and Giannetti and Ongena, 2012) to match an SME-bank relationship at a disaggregate level. This approach is by far known as the most appropriate way to explore bank firm relationship for SMEs with an absence of loan-level data and, it has been widely used by European Central Bank, European Investment Bank, Centre for Economic Policy Research, etc. since 2015. Same as above literature, we collect creditor information from Kompass to match a pair of SME and bank. The bank-firm relationship in Kompass is defined as a firm's primary bank as the most preferred short-term and long-term bank debt lender, which also provides services of depositing, cash management and others. Such a firm-bank relationship has been found to be very sticky and bank switching behaviour is very rare in EEA countries (Ongena and Smith, 2001; Chodorow-Reich, 2014), particularly in the Amadeus database (KalemliOzcan et al., 2019; Giannetti and Ongena, 2012 and Marco, 2019). In addition, bank debt in European countries is the most important source of SME finance, and in consistent with the literature above, SMEs' debt financing data from Amadeus is a valid proxy of lending from their main banks. SMEs may over-report or hide the identity of their main banks for strategic reasons (Diamond, 1991 and Yosha, 1995) but Kompass has access to credit registries information, making strategic reporting of bank relationship becoming pointless (Giannetti \& Ongena, 2012 and Brown, 2009). Where sample firms report multiple main banks, we specify the first one for data matching because as instructed by Kompass, ranking follows the order of importance of financing. Empirical studies, e.g. Giannetti and Ongena (2012), Marco (2019), Kalemli-Ozcan et al. (2019) and Ferrando et al. (2015) have shown that in this database, there is no evidence that firms with multiple relationships tend to report their preferred ones for reputational or other reasons.

standards, legal forms, status, industries, creditor information and activity locations (e.g. crown dependencies). More sampling details are available from the authors on request.

${ }^{2}$ We consider only commercial banks, savings banks and cooperative banks for generating market power variables in the full bank database and for the bank-firm matching process. 
Amongst all the banks manually matched ${ }^{3}$ with sample SMEs as their primary banks in 19 EEA countries ${ }^{4}$, there are some banks serving as few as $5 \mathrm{SMEs}^{5}$, Barclays plc serves as the primary bank for 4,879 SMEs and a typical bank works as a primary bank for 143 firms with a median of 25 in our sample. Our final sample consists of 3,349 banks where 533 of them are matched with 78,531 SMEs between 2007 and 2015 in 19 EEA countries. In terms of firm-year observations, British, French, Spanish and German SMEs contribute to $79.5 \%$ of the total observations, and $32 \%$ of the sample SMEs operate in wholesale and retail sector with another $24 \%$ in manufacturing sector (Table 1).

\section{(Insert Table 1 about here)}

\subsection{Variables}

\subsubsection{Dependent variables}

Following Love and Peria (2012), Mudd (2013) and Leon (2015), we define access to finance, $A 2 F$, as a dummy where it is coded as one if an SME's total debt is more than $5 \%$ of its total assets. Similar to Love and Peria (2014), our descriptive statistics show that about $65 \%$ of observations have $5 \%$ more total debt ratio with a standard deviation of 0.48 . In following robustness tests, we also define alternative dummy variables to measure SME access to finance as ' $1 \%+$ bank debt' and ' $10 \%+$ bank debt'. In addition, we use continuous variable 'Total debt ratio (TDR)' to measure the ratio of total debt scaled by total assets by following Daskalakis et al. (2017), Ayyagari et al. (2016); Bougheas et al. (2006); Sufi (2009) and Gonzalez and Gonzalez (2008).

Tables 2 and 3 report the distributions of these two key variables across countries and industries and over time where the statistics of 'Total debt ratio (TDR)' are weighted by total assets of SMEs. 'A2F' in the regression analysis is interpreted as the likelihood of access to finance and 'Total debt ratio' is the real level of financing. These two variables capture the financing constraints of SMEs after controlling for the heterogeneities in regards to credit demand, credit supply and firms' capabilities of obtaining finance. Table 2 shows that for SMEs in some countries, the patterns of percentage of SMEs access to finance and total debt ratio are not always consistent, advocating the necessity of distinguishing the measures from the viewpoints of probability of access to finance and debt finance usage. Table 3 shows that SMEs' dependence on finance varies significantly across industries and we address this issue in the following robustness tests by considering industry-level differentiation and loan growth rates.

\footnotetext{
${ }^{3}$ We manually match two databases instead of using text-processing software such as OpenRefine (used in Kalemli-Ozcan et al., 2019) for the considerations of accuracy, different reporting formats (e.g. abbreviation, Unicode), actual lending activities (e.g. bank M\&A) and uncertainty (i.e. unsure relationship detected given only the names of banks). Details are available from the authors on request.

${ }^{4}$ Amadeus does not have debt information on Danish SMEs and Kompass does not have bank-firm relationship information for the remaining 11 EEA countries and Switzerland.

${ }^{5}$ We exclude banks if they are matched with five or less firms for simplicity and the removal of uncertainty in regression analysis. Most of the banks being removed are very small banks in each country and operate at very local level, firms matched with these banks have extremely insufficient accounting data, thus this exclusion process does not affect our regression analyses.
} 


\section{(Insert Table 2 about here)}

(Insert Table 3 about here)

\subsubsection{Bank market power}

Bank competition can be measured using either structural methods based on the Structure-ConductPerformance paradigm (SCP) or non-structural methods based on the 'new empirical organisation' theories (Leon, 2014). The use of structural methods, such as concentration ratio and HHI, has been challenged by the concept of market contestability (Bolt and Humphrey, 2015) because structural measures may proxy market condition rather than market power (Ergungor, 2004; Stein, 2002). The theoretical foundation of SCP is rejected by Claessens and Laeven (2004) and Northcott (2004). Lapteacru (2014) finds that in the European market, concentration is not related to the market power of banks and competitiveness of a banking market. Bolt and Humphrey (2015) empirically show that concentration measure (HHI) is not statistically correlated with other non-structural measures. In addition, bank market power measured at country-level cannot capture the direct and distinct effects of banks with different level of market power on firms in a country. And, in regression analysis, countrylevel measures matched with firm-level data could overstate the significance of coefficients as the degree of freedom is miscalculated (Ergungor, 2004). Hence, in this study we need a non-structural bank market power measure that is set at a disaggregate level.

Three non-structural indicators can be calculated at bank-level, Boone indicator (2008), PanzarRosse H-statistic (Panzar and Rosse, 19982, 1987) and Lerner index (Lerner, 1934). The Boone indicator has lack of literature foundation at bank-level and its theoretical foundation has been challenged by the causality between bank efficiency and market power (see Phan et al., 2016 and Cipollini and Fiordelisi, 2012). The H-statistics can be set at bank level but it requires a prerequisite that the banking market must be in a long-term equilibrium (Bikker et al., 2012; Claessens and Laeven, 2004). We test the long-term equilibrium by using bank profitability models by following Athanasoglou et al. (2008), but our results suggest that the $\mathrm{H}$-statistics is not a valid measure in our sample ${ }^{6}$. Hence, we adopt Lerner Index (see Appendix A for derivation) as a non-structural measure of disaggregatelevel bank market power, which considers the pricing power of a specific bank identified by the divergence between its revenue-based price and its marginal cost ${ }^{7}$. Table 4 shows the country level Lerner indices that are weighted averaged by bank total assets over time. For comparison, country level $\mathrm{HHI}$ is also demonstrated. A higher value of Lerner index indicates a greater market power and a less

\footnotetext{
${ }^{6}$ Under equilibrium, bank profitability should be invariant with input prices. We test this assumption separately in each country and find that most banking markets are unlikely to be in a long-term equilibrium. Full testing results are available on request from the authors.

${ }^{7}$ Practical limitations include, first, pricing market power is not necessarily a proxy of competition since market power and competition can be, under specific cases, consistent with same direction (Bulow and Klemperer, 2002). Second, Lerner Index could be overstated because bank's pricing decision is endogenously related to its risk preference on taking disparate projects. However, besides these imperfections, it is still regarded as the most applicable indicator at bank level.
} 
competitive banking market. The values of country-level Lerner indices we calculated are very close to the World Banks' release. Table 4 shows that for many countries, banking market competition level increased during financial crisis period but have decreased since 2011. German, Dutch and Portuguese banking markets are overall more competitive compared with other EU countries. British banking market has gradually become more competitive since 2010 but it is still less competitive than France and Germany. Results from Lerner Indices and HHI show different trends and orders in comparisons, and the coefficient of correlation (not reported) between HHI and Lerner index is less than 0.1, all suggesting that these two measures are not interchangeable and their implications are dissimilar.

\section{(Insert Table 4 about here)}

A criticism has been raised by Maudos and Guevara (2007) on the traditional Lerner Index calculated as in Appendix A that, banks with greater market power on deposit market have lower cost of funds, which is transferrable to lending market and thereby overestimate bank's market power on lending market. Such a bias could be enlarged if a bank's lending price is sensitive to its marginal cost. Regarding to this criticism, Maudos and Guevara (2007) and Turk-Ariss (2010) propose a solution to simply drop the cost of funds variable in the trans-log cost function (eq. A1, Appendix A) because the variable reflects the bank market power on the deposit market. However, Forssbeck and Shehzad (2015) point out that the solution could also produce bias. First, since the trans-log cost function must hold assumptions of homogeneity in input prices, their proposed treatment leads to estimations being carried out with only one input price, therefore underestimating the cost to output ratio and upwardly distorting the Lerner Indices. Second, dropping the price of funds variable as a solution is only applicable when the assumption that a bank's marginal cost is irrelevant to the cost of funds and deposit rate holds; otherwise the measure would overstate the effect of lending rate. Empirical evidence has shown that bank market power at deposit market and lending market are not associated with each other (e.g. Williams, 2012; Forssbeck and Shehzad, 2015). We therefore measure the market power of a bank specifically at the lending market for robustness tests by following Forssbeck and Shehzad (2015, see Appendix A).

\subsubsection{Control variables}

\section{Bank level control variables}

To control for the factors affecting credit supply at bank-level, we include bank size (natural logarithm of total assets), bank capital risk (equity to total assets ratio) and activity structure (non-conventional banking activities). We follow Delis and Kouretas (2011) to measure the non-traditional activities of a bank by its off-balance sheet items to total assets. In robustness tests, we follow Williams (2016) and 
use the ratio of non-interest income to total bank income ${ }^{8}$. In addition, we control for bank cost efficiency by cost to income ratio, and control for intermediary efficiency by applying the Data Envelopment Analysis (DEA efficiency).

\section{Firm level control variables}

We control for firm level characteristics by firm size (natural logarithm of total assets), age (natural logarithm of firm age plus one), innovation dummy ${ }^{10}$, industry and legal form. Additional firm level control variables are related to SMEs' external financing capabilities, such as tangibility (tangible assets/total assets), profitability (ROA), and SMEs' demands for external financing, such as cash richness (cash/total assets net cash), liquidity (current assets net stock/current liabilities), trade credit usage (net creditors or debtors scaled by total assets.) and growth opportunity at industry level which is measured as weighted averaged sales growth rate (Behr et al., 2013) and weighted averaged ratio of intangible assets to fixed assets (Di Patti and Dell' Ariccia, 2004) in robustness tests.

\section{Macroeconomic and banking market controls}

Credit supply side heterogeneities are controlled by aggregate-level variables, i.e. GDP growth rate, importance of banking section (domestic credit to private sector by banks, as a percentage of GDP, Delis and Kouretas, 2011), banking market concentration (HHI) and country-level growth rate of the number of banking branches ${ }^{11}$. We report definitions and sources of variables in Appendix B and descriptive statistics in Table 5.

\section{(Insert Table 5 about here)}

\subsection{Baseline models, econometrics and model validity}

To investigate the effects of bank-level market power and other determinants on SME finance, we employ the following baseline models. First, we model the likelihood (Eq. 1) of an SME having access to bank finance with the dependent variable (A2F) coded as 1 if a sample firm in a given year has an amount of bank finance that is greater than $5 \%$ of its total assets. We also run a model on the total debt

\footnotetext{
${ }^{8}$ For a review of the effects of bank activity diversification on bank profitability, risk, bank lending channel and SME cooperation, see Meslier et al. (2014) and Perera et al. (2014).

${ }^{9}$ Follow Tan and Floros (2013), we use input-oriented, two-stage variable returns to scale, intermediation approach techniques and Ji and Lee's (2010, revised online in 2014) programming codes to calculate the DEA scores. The DEA scores range from 0 to 1 , representing least to most intermediary efficient. Our cross-country evidence shows that British and French banking markets are most intermediary efficient and Portuguese and Slovenia are least efficient. Full details of generating DEA efficiency scores and cross country-year DEA score tables are available on request from the authors.

${ }^{10}$ The dummy variable is coded as 1 if an SME has ever had a patent or a trademark; 0 otherwise. Innovation activities carry more information asymmetries. One limitation of this binary variable is that the data is timeinvariant. We acknowledge that $R \& D$ expenditure could be a better indicator but only $8 \%$ of our samples report $R \& D$ expenditure.

${ }^{11}$ Studies such as Bellucci et al. (2015) and Han and Benson (2010) have documented the importance of physical branch to SMEs' access to finance.
} 
ratio (TDR) as specified by Eq. 2. The merits of separating these two equations are threefold. First, results can be interpreted differently from either the views of the probability of access to finance or debt financing ratio. Second, our descriptive statistics (Table 2) show big country and industry level variations between these two measures. For example, in some countries and industries, the proportion of SMEs that have access to finance (A2F) is high but the actual debt financing usage (TDR) is low, and vice versa. By estimating these two groups of equations with different dependent variables, our results provide a more complete picture of the bank financing conditions of SMEs. Third, we use alternative measures for robustness checks by employing different estimators (e.g. panel Probit vs. fixed-effects).

Prob. $\left(Y_{i j c t}=1\right.$, Access to Finance $)=\alpha+\beta B_{b t}+C_{1} F_{i j c t(t-1)}+C_{2} M_{c t(t-1)}+C_{3} B_{b t}^{\prime}+\varepsilon_{i j c t}$

$\mathrm{Y}_{\mathrm{ijct}}\left(\frac{S T+L T \text { bank debt }}{\text { firm total assets }}\right)=\alpha+\beta \mathrm{B}_{\mathrm{bt}}+\mathrm{C}_{1} \mathrm{~F}_{\mathrm{ijct}(\mathrm{t}-1)}+\mathrm{C}_{2} \mathrm{M}_{\mathrm{ct}(\mathrm{t}-1)}+\mathrm{C}_{3} \mathrm{~B}_{\mathrm{bt}}+\left(\theta_{\mathrm{ijc}}\right)+\left(\tau_{\mathrm{t}}\right)+\varepsilon_{\mathrm{ijct}}$

In the equations, $Y_{i j c t} s$ are the access to finance measures discussed above for firm $i$ in industry $j$ country $c$ and at time $t$, subscript $b$ denotes the matched bank with firm $i . \theta_{i j c}$ refers to firm-level fixedeffect (fixed-effects models), or industry-level and country-level dummies (random-effect models), and $\tau_{t}$ is time fixed-effect. Matrix $B$ includes bank market power variables. $F, M, B$ ' are sets of firm-specific, country-level and remaining bank-level determinants ${ }^{12} . \varepsilon_{i j c t}$ is a disturbance term consisting of unobservable individual time-invariant specific effect, potential time-effect and remainder disturbance.

Limited dependent variable models (LDVMs, eq. 1) are estimated by random-effects panel Probit estimator to retain the advantage of panel data structure on time-series difference. We also run fixed-effects Logit models for robustness test although it significantly sacrifices the number of observations. Total debt ratio models (eq. 2) are estimated by both random-effects maximum likelihood estimator and fixed-effects estimator. The maximum likelihood estimation fully maximises the likelihood of the random-effects models thus it is an ideal estimator when dealing with large observations. It also allows us to add time-invariant binary independent variable (e.g. innovation) and controlling dummies in the right-hand side ${ }^{13}$. However, the Hausman tests suggest that within-groups estimator is more consistent and thus we also run fixed-effects models.

Before moving onto empirical analysis, we examine the validity of our data and model specification. There are two possible causes of endogeneity problems, omission of variables and reverse

\footnotetext{
${ }^{12}$ Instead of using winsorization and extremity truncation, we manually detect and remove outliers from our firm and bank databases to ensure the quality of data without sacrificing too many observations. Around $0.25 \%$ of the original data are excluded from our sample. Our correlation matrix suggests that all independent variables are not correlated to the degree that causes multicollinearity concern in our models $(>0.6)$. Full cleaning processes and the correlation matrix are available on request from the authors.

${ }^{13}$ Our results still hold by using either basic generalised method of moments random-effects estimator or SwamyArora random-effects estimator with White cross-section coefficient covariance method and number of degree of freedom correction.
} 
causality, respectively. Several arguments based on which possible omission variable endogeneity problem can be reduced. First, control variables are added comprehensively according to corporate finance and banking theories and literature, therefore reducing the apprehension of omitted variables. Second, the panel structure of this dataset allows the inclusion of firm-level fixed effects and thus remove all time-invariant unobservable effects (Fungacova et al., 2017). Moreover, our empirical models are less likely subject to reverse causality endogeneity because, first, our bank market power variables are computed at bank-level from Fitch Connect database, while dependent variables are firmlevel characteristics coming from a different data source (Amadeus). It is therefore unlikely that debt financing variables can influence bank market power. This argument accords with Fungacova et al. (2017), Mudd (2013), Love and Peria (2012) and Leon (2015). Second, loans made to SMEs account for only a small fraction of banks' businesses and therefore general bank characteristics such as market power or efficiency can hardly be affected by SME borrowing, especially that our analysis is comprising of a representative sample that is relatively small compared to the whole SME population. Third, our derivation of market power measure is based on bank-level data, and there is no evidence that SME financing behaviour would directly impact the variables formatting our market power indicators (e.g. Lerner index). Despite the above arguments, we perform in the robustness tests baseline estimations by lagging the bank market power variables and/or other explanatory variables by one year to avoid contemporaneous reverse causality. Additionally, we apply instrumental variables estimations and Generalised Method of Moments (GMM) estimations to correct for the potential endogeneity.

Another econometrical concern could arise on selection bias where the regression results may reflect the pre-existing firm-bank relationship such that firms with certain types of financing behaviour tend to initially cooperate with banks with certain characteristics (e.g. market power, efficiency, size). This concern is only at horizontal dimension (cross-sectional) but not vertically (time-series) since the panel data setting controls the latter. To detect such a potential selection bias problem, we run an Intraclass Correlation Coefficient test (ICC) to examine whether a type of bank is connected to certain firms with similar characteristics. The ICC shows how strongly for a specific attribute of units using the same groups of banks resemble each other ${ }^{14}$. The results suggest that the pre-existing bank-firm relationship selection bias is likely to be insignificant and thus further treatment (e.g. Heckman correction) is not necessary.

\footnotetext{
${ }^{14} \mathrm{We}$ classify ICC response group into three. They are firm-level variables that are unlikely to be affected by bank characteristics (e.g. industry, age), moderately likely to be affected (e.g. total assets, employees) and those likely to be affected (e.g. cash-richness, profitability). All variables are available from accounting information and we do not carry out test on estimated variables (e.g. Tobin's Q). We do not categorise bank variables into groups because a bank itself uniquely defines a group of characteristics. Our findings show that SMEs with certain level of size (employees) in Cyprus and Latvia tend to work with certain types of banks. In addition to this, it is found that no other characteristics across SMEs are intraclass-correlated to any individual bank in all countries. Full test results and detailed explanations are available from the authors on request. See Donner (1986) and Marchenko (2006) for more information on the ICC.
} 


\section{Empirical Results}

\subsection{Baseline results}

We present our baseline results in Table 6. The first three columns are limited dependent variable models (LDVMs, eq. 1) and the next four columns are panel data models (PDMs, eq. 2). For the LDVMs, Model 1 contains all control variables and Model 2 is the simplified model where some control variables that could bring econometrical concerns are removed. Model 3 substitutes the Lerner index by the market power measured at lending market. Panel data Model 4 is estimated using random-effects maximum likelihood estimator with time, industry, country and firm legal-form dummies, and also allowing the existence of time-invariant variable firm innovation. The last three columns are estimated using fixed-effects estimator where Model 5 contains all control variables ${ }^{15}$ and both time and crosssection fixed effects. Models 6 and 7 are simplified versions ${ }^{16}$ of Model 5 and we drop the time fixed effects following Baum (2006) which suggests that estimating an equation from firm microdata implies that macro-factors such as GDP growth rate cannot be added in a model with time fixed-effects because such factors do not vary across firms.

For our main interested variable bank market power, starting with LDVMs, Lerner index and lending market Lerner index have consistently negative and statistically significant coefficients. The intuitive conclusion at disaggregate level is that SMEs have less chance to obtain debt finance from banks with higher market power, or in less competitive banking market if the result is concluded at country level. The Lerner index has a mean value of 0.232 , median of 0.234 and a standard deviation of 0.109 and the statistics are very close to a worldwide study (Love and Peria, 2014) and a European study (Fungacova et al., 2017). Using Model 1 as an example, a one standard-deviation increase in Lerner index leads to an approximately $4.5 \%$ decrease in the probability of having access to finance. In this model, the mean value of the dependent variable is 0.65 , which can be treated as the probability of a random firm having access to bank finance. Thus, a $4.5 \%$ increase (decrease) is modest for an average firm-bank pair but it is more economically important for those firms that initially had less chance to be financed. Move on to the total debt ratio models, all the coefficients are stable in terms of sign and value and they are all significant at $1 \%$ level, indicating that bank market power at bank level reduces the debt financing of SMEs, worsens their credit constraints after controlling substantially for financing capability, credit supply and demand heterogeneities. Models 6 and 7 show that, with a one standard deviation increase (decrease) in Lerner index, the debt ratio of SME deviates approximately $2.3 \%$ from its median or $1.4 \%$ from the mean value. Furthermore, a one standard deviation change in Lending market Lerner index results in the debt ratio of SMEs deviates 3.5\% from median or $2.2 \%$ from mean.

\footnotetext{
${ }^{15}$ We remove profitability variable in the panel data model as it could present endogeneity problem and as shown in the panel probit models where the sign of variable is not as expected. The possible reason is that it captures not only the profitability of a firm (as an indicator of risk level) but also the retained earning a company has (an indicator of credit demand).

${ }^{16}$ We drop those control variables that could be subject to econometrical concerns such as bilateral proxy or endogeneity, full explanation is available from the authors on request.
} 
Because the changes of debt ratios should be mainly determined by firm-level credit needs and their capability of financing but less dominant for banking sector factors, we conclude that the effect of the market power on the debt ratio is economically meaningful.

The above findings suggest that bank market power reduces credit availability to SMEs at disaggregate level, supporting Market Power Hypothesis where market power enables banks to engage in anticompetitive activities (e.g. restricted loan supply, manipulated lending rates), thereby intensifying SME financing constraints. Our results also support Competition-Fragility Hypothesis where market power reduces the incentives of banks to invest in risker projects (e.g. SME lending). At country-level, SME credit availability is improved in a more concentrated banking market as captured by higher HHI, where concentrated banking market with less market participants or significant shares of top banks may benefit from easier regulation and supervision, resulting in reduced information asymmetry. The coefficients of $\mathrm{HHI}$ in baseline models suggest that concentration is more capable of explaining firm's probability of access to finance but less economically significant in explaining the variation of total debt ratio ${ }^{17}$. We acknowledge the arguments on the relationship between bank market power and concentration in literature and therefore HHI index is removed in some baseline models to check if market power measure still presents a consistent result. We also perform tests by dropping Lerner index but keeping HHI and our results, not reported but available on request, are unaltered.

In analysing other banking explanatory variables, we note that the coefficients of bank leverage are significantly negative in all models but if we treat the variable as an indicator of bank risk-taking level, the result violates the hypothesis that bank risk-taking promotes SME credit supply (CarboValverde et al., 2009). We therefore remove this variable in the simplified models and redo the examination on the relationship between bank credit risk-taking level and SME credit availability. Our results confirm that bank taking higher level of credit risk is associated with lower SME financing constraints ${ }^{18}$. Our baseline results also show that smaller banks are more actively engaged in relationship lending and provide more credit to SMEs, consistent with de la Torre et al. (2010). However, the empirical results in PDMs are not robust, we drop the bank size variable in the simplified model since it is found that the variable is moderately correlated with our bank efficiency measures. Next, we show evidence that bank credit supply to SMEs is reduced when they engage more in non-conventional businesses such as non-interest incomes regardless of how activity structure is measured (off-balance sheet item ratio or non-interest income ratio) and this is possibly because that non-conventional businesses would negatively affect the liquid asset available for lending. In addition, since nonconventional business of banks is normally riskier, banks may diminish its risk level by engaging less in SME lending. Last, we show that the coefficients of bank intermediary efficiency (DEA scores) are all significantly positive, indicating that SMEs' financing constraints reduce when their creditors'

\footnotetext{
${ }^{17}$ Results still hold if $\mathrm{HHI}$ is replaced by concentration three $\left(\mathrm{CR}_{3}\right)$ or concentration five $\left(\mathrm{CR}_{5}\right)$ ratios.

${ }^{18}$ We use both ex-ante and ex-post measures for credit risk and, full test results are available from the authors on request.
} 
intermediary efficiency improves. This supports the view that effective resources allocation (intermediary process) stimulates the amount and quality of business activities by reducing financial frictions and better channelling available credit, therefore encouraging economic development and alleviating business lending obstacles. The results of later robustness checks show that cost efficiency (cost-to-income ratio) can also relax the financing constraints of SMEs, supporting the conjecture that banks transfer their cost savings to invest in relationship building or obtain soft information that would both benefit SMEs to have better access to finance.

Moving onto country-level variables, bank branch closure (or lower growth rate) reduces the access of SMEs to debt finance and increases their financing constraints, in line with our conjecture that branching closure has adverse effects on relationship lending and financial assistance, increases geographical restrictions for SMEs. We also show that when the conventional banking sector is more important than other sources of finance (Delis and Kouretas, 2011) and/or when the banking market is more developed (Larrain, 2006), SMEs are less credit constrained. As expected, the positive sign on the coefficient of GDP growth rate shows that SMEs demand more credit and banks are more willing to lend in the time of economic boom.

At firm-level, our results show that SMEs are more likely to be financially constrained if they are more informationally opaque such as they are younger, smaller or/and involve in innovation activities ${ }^{19}$. Cash-richness and liquidity, which are used to reversely measure credit demand, are all negatively associated with SME credit supply, and our results still hold when their one-year lagged values are used. Tangibility as a proxy of collateral capability is a strong positive determinant in all models. We also show that a one standard deviation decreases (increases) in net trade credit usage leads to an increase (decrease) of approximately $15.8 \%$ in the probability of having access to finance or $3 \%$ higher in total debt ratio. However, there could be bidirectional effects as discussed by the classic 'substitution hypothesis', whereby trade credit acts as a substitute to bank credit especially when a firm has less capability in accessing bank credit, or when bank lending is tightened or costly (Carbo-Valverde et al., 2016), meaning that a higher value of trade credit could be a result of inadequate level of bank credit accessibility. Hence, to eliminate this strong reverse causality endogeneity concern, trade credit usage is internally instrumented in the robustness tests, and it is otherwise removed from our simplified models given that a firm's trade credit usage would not affect our bank market power indicators. Finally, SMEs operating in industries with higher growth opportunity are likely to demand more finance and, our results are robust irrespective of the classification of industry and whether growth opportunity is measured using intangible assets ratio or sales growth rate.

\section{(Insert Table 6 about here)}

\footnotetext{
${ }^{19}$ Age variable is criticised to be not ideal in panel data setting as it increases the same increment each year across all the firms and thus it is dropped in the simplified models. Because the dummy variable innovation is timeinvariant, it is not possible to be added in fixed-effects models and it is not ideal to be included in panel Probit models. Results do not change if the measure is proxied by only patent but not trademark.
} 


\subsection{Robustness tests}

We examine the robustness of our baseline results for the two equations (probability LDVM models and total debt ratio models), respectively. The first set is presented in Table 7 and second set in Table 8. Control variables in all robustness check models are those used in above simplified models, unless otherwise stated.

Start with the LDVM models (Table 7), first, we change the threshold of the variable 'Access to Finance (A2F)' to $1 \%$ and $10 \%$ of total assets (originally $5 \%$ ). Results from first two columns show that bank market power measure is still significantly negative although the magnitude of Lerner index effect in the 10\% threshold model declined, suggesting that bank market power effect is weakened for firms attempting to access to higher level of finance. The third model tests the robustness when an SME is treated as different entities across years by a cross-section Probit model. Pseudo $\mathrm{R}^{2}$ of $14.2 \%$ suggests that the overall goodness-of-fit is satisfactory and the significant coefficient of Lerner index supports the baseline results. Next, we adopt fixed-effects panel Logit estimator to run the model where the assumption of Probit distribution is not possible due to the Incidental Parameters Problem (Lancaster, 2000). The fixed-effects panel logit estimator does utilise all the essential information on the binary variable although the number of observations drops to just over 130,000 , because this estimator requires a value change of dependent variable after differentiating the model in two continuous years. Our baseline results still hold and the coefficient of Lerner index remains significantly negative. Next, we lag the Lerner index in Model 5, and lag both Lerner index and controls in Model 6 to address contemporaneous reverse causality, and our main findings remain unchanged. We also perform tests in these six models substituting Lerner index by lending market Lerner index and our baseline results still hold. Finally, Models 7-11 are estimated by Newey's (1987) two-step pooled instrumental variable probit estimator to address potential endogeneity concerns. These results are for reference only because it cannot be set as a panel form. The selection of instruments is discussed as below together with panel data models robustness checks.

\section{(Insert Table 7 about here)}

Moving onto the continuous dependent variable models (PDMs, equation 2) in Table 8, for the first three columns, we restrict our sample to those observations which have access to bank finance (i.e. greater than $1 \%$ and $10 \%$ of total assets). The number of observations declines gradually from 366,060 (Model 6, Table 6) to 204,326, and the coefficients of Lerner index are all negative and significant. The fourth column sets the data in a cross-section form. We use Cochrane-Orcutt transformation regression estimator to address the autocorrelation concern as suggested by the Lagrange multiplier test and we allow for robust standard error to address heteroskedasticity. All results remain consistent even if basic OLS estimator is employed. Models 5 and 6 adopt growth-rate-based dependent variables where the former is calculated as the two-year moving average growth rate of total debt ratio and latter by moving 
average growth rate of the amount of debt financing by following Ayyagari et al. (2016) and Haltiwanger et al. (2013). Results indicate that an increase in bank market power (less competition) has a negative effect on firm's financing growth rate, essentially consistent with the baseline findings.

One might argue that, as shown in Table 3, there are inherent differences in terms of the nature of financing demand and financing capability across different industries. Although control variables and fixed-effects have represented cross-industry financing habit heterogeneities and standard-errors have been tested to be clustered at industry-level instead of individual-level, we still perform Model 7 by replacing the dependent variable by the difference of total debt ratio from industry weighted (by total assets) averaged level across years to eliminate the natural heterogeneities of financing behaviour across different industries, where a positive value (higher value) implies an SME accesses to more finance than industry standard and vice versa. Our results show that bank market power is negatively related to an SME's financing level compared with its industry standard in which it operates, confirming the baseline results. In Model 8, we re-specify the panel data models in a form that transforms both dependent and independent variables into their one-year difference to capture the effects of real change $\mathrm{x}$ variables on $\mathrm{y}$ variables ${ }^{20}$. The change of Lerner index is significantly negatively related to the change of bank debt financing ratio. Model 9 accounts for omitted variable concern of unobservable bank-level factors by including bank-level dummy variables ${ }^{21}$ along with country and industry dummies in a random-effects maximum-likelihood estimation. Results confirm that our key findings on bank market power variable are not biased reflections of other banking effects.

We further address the omitted variable and reverse causality endogeneity concerns as follows. First, we lag Lerner index by a one-year period (Model 10) and, both Lerner index and control variables by a one-year period (Model 11), to address the potential reverse causality concern given the belief that future does not affect past. Second, we adopt instrumental variable estimation technique ${ }^{22}$ to address the endogeneity concerns on bank market power and some control variables. We follow Fungacova et al. (2017), Tian et al. (2019) and Anginer et al. (2014), instrument disaggregate-level bank market power by its own lag transformation(s), lagged bank profitability, lagged net interest margin adjusted by nominal interest rate, lagged tier-1 capital ratio and a mixture of them ${ }^{23}$. These papers argue that the past levels of bank performance are a determinant of the acquisition of future market power, the past levels of bank's net interest revenues as a share of tis total earnings assets could reflect as a sign of the degree of market power gained by a bank in terms of pricing power, and those banks with higher Tier-

\footnotetext{
${ }^{20}$ We thank an anonymous referee for suggesting this approach.

${ }^{21}$ Among the 504 bank dummies being included, only 11 of them $(2.2 \%)$ are statistically significant at $5 \%$ level, possibly meaning that the omitted variable concern of bank characteristics is not severe.

${ }_{22}$ Be more specific, we employ a "two-stage-least-square instrumental variable fixed-effect estimator with robust standard errors" to perform the estimations. We also adopt a "two-stage-least square instrumental variable firstdifference estimator" which provides qualitatively indifferent results (not reported). However, one drawback of the latter estimator is that it sacrifices a significant number of observations.

${ }^{23}$ The correlation coefficients between the three instrumental variables (ROA, adjusted NIM and Tier-1 ratio) and Lerner index in our "whole bank" dataset are respectively, $0.22^{* * *}, 0.22^{* * *}$ and $0.14^{* * *}$.
} 
1 capital ratio would have a better ability to accumulate capital to build a buffer against failure and to set up barriers for other market participants on the equilibrium path. Results ${ }^{24}$ are presented in Table 8 (Models 12-16). Third ${ }^{25}$, we re-specify the PDM baseline model into dynamic form and adopt the Generalised Method of Moments $\left(\mathrm{GMM}^{26}\right)$ estimation technique to correct for the endogeneity of lagged dependent variable and potentially endogenous explanatory variables (e.g. bank market power). In Table 8, we adopt both 2-stage 'Difference' GMM (D-GMM, Model 17) estimator by Arellano and Bond (1991) and 2-stage System-GMM (S-GMM, Model 18) estimator by Arellano and Bover (1995) and Blundell and Bond (1998) ${ }^{27}$, with the Windmeijer correction (2005) technique to reduce the downward bias of standard errors. In addition to the lagged dependent variable, GMM allows treating other explanatory variables, in our case, bank market power and other firm-level controls, by using lag transformations as instruments. The lag length of these instruments is chosen on the basis of the overidentifying restriction tests for instrument validity, and error terms serial correlation tests ${ }^{28}$. All the above three approaches that aim at correcting endogeneity biases confirm the robustness of our main findings on bank market power variable. Moreover, the lagged total debt ratio enters the models with a significantly positive sign with a coefficient in the region of 0.5 , signifying the dynamicity of dependent variable.

Apart from the tests reported in Table 8, we also substitute Lerner index by lending market Lerner index for all models and results confirm the main finding. We also include the squared terms for the market power measures in the baseline panel data models and our results support a linear relation. For the static panel data models, we acknowledge that our sample may not satisfy the assumption of independent and identical distribution because the error terms for an individual during different time periods are often autocorrelated. We therefore run our fixed-effects models with autoregressive model of order 1 disturbance with two-step estimate of correlation, all results align with our baseline findings.

\footnotetext{
${ }^{24}$ Several econometric diagnostic tests are conducted (reported), along with F-statistics of Sanderson-Windmeijer multivariate test, $\mathrm{t}$-statistics of the instrument list from first-stage regression, and the Durbin-Wu-Hausman test (not reported), conclude the necessity of IV approaches and the appropriateness of our selected instruments, except for the instrument 'bank Tier-1 capital ratio', which does not pass the Hansen test.

${ }^{25}$ We thank an anonymous referee for this suggestion.

${ }^{26} \mathrm{GMM}$ estimator is documented to be a rigorous treatment when dealing with endogeneity problems of both dynamic and static explanatory variables (Harris et al. 2013; Leroy, 2014) and it is also documented to be more efficient than the 2SLS estimator in the presence of heteroskedasticity (Bos et at. 2013).

${ }^{27}$ The D-GMM takes first difference of the original model, therefore removes both the constant term and the individual effect, and endogenous variables can be instrumented by lagged levels. However, a weakness is that the lagged levels are often rather poor instruments, especially if the variables are close to a random walk (Baum, 2006). Therefore, Arellano and Bover (1995) and Blundell and Bond (1998) modify the estimator in an equation system by including lagged levels as well as lagged differences (S-GMM). Roodman (2009) has shown that twostage estimator is asymptotically more efficient than one-stage estimator.

${ }^{28}$ If a second-order serial correlation exists, lags from period t-3 (and onwards) for lagged dependent variables, and lags from period t-2 (and onwards) for static endogenous variables, can be used as instruments (Bos et al., 2013; Daskalakis et al., 2017; Ding et al., 2013; Baum, 2006, page 265). Based on the results of AR(n) and overidentifying tests, lagged independent variable is instrumented by its $\mathrm{t}-3$ and $\mathrm{t}-4$ transformations and, $\mathrm{t}-2$ transformations for endogenous explanatory variables. Longer lags are not included because in that case, the equations are overidentified.
} 
In addition, we adopt different methods when estimating our Lerner indices (see appendix A), replace each of our control variables including bank variables by their alternative measures and run the baseline models with different combinations of control variables, and split our sample into different countries (big 4 countries vs. others) and years (pre and post 2010) in both equations (1 and 2). Our baseline results still hold ${ }^{29}$.

\section{(Insert Table 8 about here)}

\subsection{Heterogeneity tests}

Above baseline and robustness test results show clear and consistent evidence that bank-level market power has unfavourable effects on SME access to finance and financing constraints. Such effect could vary over firm and macroeconomic characteristics. In this section we further test the sensitivity and heterogeneity of such effects by using both grouping and interactive terms (Table 9). The merits of using both approaches are threefold. First, under some circumstances, it is not ideal to group firms or generate interactive term. Second, it provides robustness checks on the moderating effects as the exact mathematical forms are less important. Third, grouping allows robustness check on baseline models to see if baseline findings are driven by a specific group of sample firms.

First, our grouping results together with interactive terms (Models 1-3) suggest that the access to finance of innovative SMEs are more sensitive to bank market power because innovation activities are recognised to be riskier and more informationally opaque and innovative SMEs usually have fewer tangible assets. We next group the samples into three from Low to High (Models 4 - 6) of the size-age index (SA index), as proposed by Hadlock and Pierce (2010) as an indicator of SME's information opaqueness purely captured by firm size and age. A lower (higher) value of the index represents that a firm is more (less) informationally opaque. Together with the interactive term Model 7, we show that younger or/and smaller SMEs are more sensitive to the adverse effect of bank market power.

We also group SMEs on industries (wholesale, manufacturing and non-manufacturing, Models 8 - 10) and show that manufacturing SMEs are more likely to be affected by the adverse effect of bank market power because they are more dependent on external finance than wholesaling and nonmanufacturing firms. Next, we examine whether cash holding mitigates the bank market power effect. The sample is grouped into three from low (left) to high (right) cash-richness (Models 11 - 13) and the other one (Model 14) uses full coverage with an interactive team. The coefficients of market power enter from left to right with highest absolute value to lowest $\left(-0.031^{* * *},-0.011^{* *},-0.008^{*}\right)$, suggesting that SMEs with higher level of cash as a precautionary investment fund are less influenced by the market power of lenders in terms of external financing. The interactive term model predicts similar interpretation. For example, considering a sample firm whose cash-richness level increases from the

\footnotetext{
${ }^{29}$ All the above test results are available from the authors on request.
} 
$50^{\text {th }}$ to $75^{\text {th }}$ percentile, the marginal effect of market power on its finance increases, equivalent to a decrease in magnitude by $26 \%$.

In addition to firm and industry variations, the bank-level market power effects also vary over market level factors, such as the banking market itself. Because the sample contains only 19 EEA economies and the country-level variations are not as significant as worldwide studies such as Beck et al. (2004) and Love and Peria (2014), grouping approach is not ideal and therefore we use interactive terms in both equations (eq. 1 and 2). Our results (Models 15 and 16) show that the unfavourable bank market power effect on credit availability to SMEs rises along with the increase of bank concentration although it is previously found that concentration itself promotes better credit supply to SMEs. However, such effect is not economically significant as shown that the coefficient of market power changes from -0.030 in less concentrated banking market $\left(25^{\text {th }}\right.$ percentile of $\left.\mathrm{HHI}\right)$ to -0.033 in more concentrated banking market ( $75^{\text {th }}$ percentile of HHI). The last two columns (Models 17 and 18) suggest an interesting result that the negative relation between bank market power and SME credit supply is stronger when the economic condition becomes better, inconsistent with the hypothesis proposed by Ruckes (2004) and Demiroglu et al. (2012). Our result is also different from Beck et al. (2004) and the possible reason is that when the economic booms, SMEs perceive better growth opportunity and are more likely to exhaust internal fund and finance externally. However, banks could be more profitable in expanding businesses with more transparent enterprises, leading to an increasing unfavourable marginal effect of bank market power on SMEs.

\section{(Insert Table 9 about here)}

\subsection{Additional tests}

By Table 10, we further examine if bank market power effect varies over the nature of external finance, i.e. short term vs. long term finance. Dependent variables are calculated as the short-term loan to total assets ratio (Model 1) and long-term debt to total assets ratio (Model 2). The coefficients of Lerner index are negative and statistically significant, indicating that bank market power has an impact on both SME short-term and long-term finance, being evidenced as an extended robustness check.

We control observations to those with access to bank finance (>1\% of total assets) and define the dependent variable in Model 3 as short-term debt to total debt ratio (STDTD) to capture the proportion of an SME financed by short-term debt. Our statistics (not reported but available) show that the proportion of short-term debt (or long-term debt) in total debt vary significantly across industries. For example, some industries, such as wholesale and retail trade, and manufacturing, rely extensively on short-term finance because of the investment cycle differences and some rely more on long-term finance such as real estate and resources supply industries. It is therefore evident that there are strong inherent (natural) differences in terms of the mixture of short-term and long-term finance usage across industries and thus we address this by generating two additional dependent variables: the difference between a firm's proportion of short-term debt in total debt and industry average (Model 4) and the 
difference based on firm size weighted industry average (Model 5). For both variables, a positive (or higher) value indicates that an SME has a higher proportion of short-term debt usage in total debt compared to its industry's standard and vice versa. The values are irrelevant to the amount of finance and the degree of financing constraints ${ }^{30}$.

The coefficients of bank market power are statistically negative in all three models, implying that those bank-financed SMEs use less short-term debt or more long-term debt when the market power of bank increases. In general, due to the high risk associated with SME lending such as high uncertainty in long-run, information opaqueness and moral hazard, banks are more likely to finance SMEs by shortterm debt and thus SMEs have to rely on the renewing of short-term finance to invest in long-term projects. This brings inefficiencies to both parties, where SMEs are finding it problematic to invest in long-rum because of the short-term repayment, and banks are likely to incur more costly screening and monitoring processes and incur more transaction costs. Our results indicate that when bank market power increases, they are more capable of building relationship with SMEs, investing in soft information and improving techniques identifying long-term creditworthiness of SMEs. Our results suggest that banks with higher market power are more likely to cooperate with SMEs in a long-term relationship basis and thus the proportion of long-term debt in debt structure is increased. Unlike the discussion in our baseline models, this finding of increased market power promoting the long-term credit supply supports the Information-based Hypothesis (IBH) where in the presence of information asymmetries and agency costs, market power motivates banks to invest in soft information (private information) acquisition and build lending relationship, leading to a promotion of credit supply to informationally opaque firms, such as SMEs. Above results still hold if we replace Lerner index by lending market Lerner index, and if the sample is restricted to those SMEs who have a higher level of total debt ratio (e.g. $>5 \%$ or $>10 \%$ of total assets).

\section{(Insert Table 10 about here)}

\section{Conclusion}

This paper studies the effect of bank market power on SME access to finance and financing constraints by using a matched bank-firm database that allows us to examine the effects at firm level. Our novel evidence from a sample containing nearly 80,000 SMEs being matched with over 500 banks in 19 EEA countries from 2007 to 2015 suggests that bank market power at disaggregate level impedes SMEs access to finance, worsens their credit constraint, bank competition promotes credit supply to SMEs if the result is translated to country level. The unfavourable effects of bank market power on firm's probability of access to finance and bank debt usage are stronger for SMEs who are more informationally opaque or higher in cash-flow uncertainty such as they involve in innovation activities or they are smaller or younger. The unfavourable effects are also more prominent for those businesses

\footnotetext{
${ }^{30}$ The difference of the number of observations across Model 3, 4 and 5 are caused by different outlier cleaning processes.
} 
which are more dependent on external finance such as those SMEs operating in manufacturing industry, having low level of cash and liquid assets and when they perceive better growth opportunity and therefore being more likely to exhaust internal funds. These findings generally show support to the Market Power Hypothesis where lower competition increases financial constraints but reject the validity of the Structure-Conduct-Performance paradigm (SCP). Our results also empirically back the Competition-Fragility Hypothesis and Ergungor Boot Thakor Hypothesis discussed in Section 2.2. We also show supporting evidence on Information-based Hypothesis where with greater market power, banks are more likely to engage in relationship lending as evidenced by more long-term lending issued to SMEs.

For other banking determinants, results indicate that SME credit constraint is alleviated in more concentrated banking markets because concentrated banking market with less market participants or/and significant shares of top banks may benefit from easier regulation and supervision resulting in reduced information asymmetry and improved efficiency of asset allocation. The effect is more favourable in explaining firm's probability of obtaining finance but less economically significant in explaining the usage of bank debt. Branching closure is found to have favourable impact on bank efficiency but it is positively associated with the financing constraints facing SMEs. At bank-level, we find that SMEs are more financially constrained if banks engage more non-conventional businesses and if they are less efficient.

The implications for policymakers derived from our empirical evidence are that policies advocating banking market competition and suppressing bank from obtaining excessive market power would have a favourable influence on credit allocation to SMEs and therefore beneficial to the financial stability and economic growth. This could be important at this moment as the interest of banking consolidation arises in European countries and this may increase the market power of large banks. However, although the banking theories can have contrasting predictions (e.g. MPH vs. IBH), similar to Han et al. (2017), we have shown that theories are not always mutually exclusive to each other as we find that banks with greater market power are also more likely to engage in relationship lending and reduce the information barriers between borrowers and lenders. The policy implication is that when promoting bank competition, policymakers must also pay attention to supporting SMEs' access to finance by reducing information barriers and building tailored relationship. Our findings are also consistent with the view that methods on targeting bank competition should be more diversified as traditional approaches such as imposing rules on changing the market structure of banks may not be useful (Carbo-Valverde et al., 2009). Another suggestion we have for the policymakers is that, since it is found that many banking characteristics could have an impact on SME finance (e.g. bank business diversification, intermediary efficiency), it is noteworthy that bank market power could have direct or indirect relationship with these characteristics and these could have conflicting effects on SME finance. Therefore, it is important for policies not to let the loss outweigh the gain. 
The limitations of our study and future research suggestions are that, our study could not directly observe the loan level details. Future studies of this filed can be improved if detailed SME loanlevel data from different banks in different countries can be made available. Second, our research focuses on a sample of 19 EEA economies but the other 12 EEA countries (e.g. Italy, Norway) and Switzerland are not included due to the lack of bank-firm relationship information from Kompass or other essential information at firm-level. Third, our financial constraint measure is based on the usage of bank finance but it does not capture the price side obstacle. High interest and non-interest costs can have detrimental effects on the survival and growth of SMEs and SMEs may suffer from excessive costs associated with satisfying their demand on finance, which may lead to an ex post moral hazard problem and financial instability. Last, future studies could further explore the determinants of bank market power and study how banks can be tackled for more efficient credit allocations to SMEs. 


\section{Appendix A: The Constructions of Lerner Index and lending market Lerner Index}

The Lerner Index is constructed following exact procedures as in Anginer et al. (2014) and Love and Peria (2014). We first adopt a trans-log total cost function as follow:

$$
\begin{aligned}
\ln (\mathrm{TC})= & \alpha+\beta_{1} \times \ln (\mathrm{Q})+\beta_{2} \times(\ln (\mathrm{Q}))^{2}+\beta_{3} \times \ln \left(\mathrm{W}_{1}\right)+\beta_{4} \times \ln \left(\mathrm{W}_{2}\right)+\beta_{5} \times \ln \left(\mathrm{W}_{3}\right)+\beta_{6} \times \ln (\mathrm{Q}) \times \ln \left(\mathrm{W}_{1}\right) \\
& +\beta_{7} \times \ln (\mathrm{Q}) \times \ln \left(\mathrm{W}_{2}\right)+\beta_{8} \times \ln (\mathrm{Q}) \times \ln \left(\mathrm{W}_{3}\right)+\beta_{9} \times\left(\ln \left(\mathrm{W}_{1}\right)\right)^{2}+\beta_{10} \times\left(\ln \left(\mathrm{W}_{2}\right)\right)^{2}+\beta_{11} \times \\
& \left(\ln \left(\mathrm{W}_{3}\right)\right)^{2}+\beta_{12} \times \ln \left(\mathrm{W}_{1}\right) \times \ln \left(\mathrm{W}_{2}\right)+\beta_{12} \times \ln \left(\mathrm{W}_{1}\right) \times \ln \left(\mathrm{W}_{3}\right)+\beta_{12} \times \ln \left(\mathrm{W}_{2}\right) \times \ln \left(\mathrm{W}_{3}\right) \\
& +\delta \times \ln (\text { netputs })+\text { firm fixed effects }+ \text { year dummies }+\varepsilon
\end{aligned}
$$

Where total cost (TC) is the sum of total interest expenses and total non-interest expenses. Output (Q) is total assets or alternatively total earning assets. $\mathrm{W}_{1}, \mathrm{~W}_{2}$ and $\mathrm{W}_{3}$ are three inputs that are cost of labour, cost of fund and cost of physical capital, measured respectively by personnel expenses scaled by total assets or alternatively scaled by total earning assets; total interest expenses scaled by total deposit and short-term funding or alternatively scaled by average interest-bearing liabilities; other operating expenses scaled by fixed assets or alternatively total non-interest expenses without personnel expenses scaled by fixed assets. Netputs include equity to total assets, net interest margin and net loans to total assets. Subscripts $b$ and t denoting bank and time are hidden for simplicity. We apply the restrictions of symmetry and homogeneity of degree on in the input prices to estimations. Measures mentioned at front are used for our main Lerner Index estimation and the alternative measures with different combinations are used for robustness checks. We run the regressions with full country-year coverage allowing for year and individual fixed effects in the full bank data (see Section 3.1). Alternatively, for generating robustness check variables, models are run within each country. Randomeffects models and pooled data with year, country and bank specialisation dummies are also tested, results do not change.

The marginal cost (MC) is the first-order derivative of the above trans-log total cost function with respect to output $(\mathrm{Q})$, shown as below (subscripts $\mathrm{b}$ and $\mathrm{t}$ hidden):

$$
\begin{aligned}
\mathrm{MC} & =\partial \mathrm{TC} / \partial \mathrm{Q} \\
& =\mathrm{TC} / \mathrm{Q} \times\left[\beta_{1}+\beta_{2} \times \ln (\mathrm{Q})+\beta_{6} \times \ln \left(\mathrm{W}_{1}\right)+\beta_{7} \times \ln \left(\mathrm{W}_{2}\right)+\beta_{8} \times \ln \left(\mathrm{W}_{3}\right)\right]
\end{aligned}
$$

We next take the marginal cost (MC) to the below formula to generate our Lerner index for each bank in each year.

Lerner Index $=(\mathrm{P}-\mathrm{MC}) / \mathrm{P}$ 
Where $\mathrm{P}$ is the price of outputs and $\mathrm{MC}$ is the marginal cost (eq. A2). Price is calculated as the gross income and dividend income together divided by total assets, or alternatively divided by total earning assets. When total assets are used as a measure of output, price $(\mathrm{P})$ must be specified by gross income plus dividend income together divided by total assets, or total earning assets as the denominator of $\mathrm{P}$ when it is used also as output measure, this is to ensure the consistency of output variables.

As discussed in Section 3.2.2, we also construct the Lerner index at lending market for robustness checks. The empirical methods of generating such a variable is exactly the same as the one used by Forssbeck and Shehzad (2015, pp. 2003) thus the details are not presented here. In brief, their paper assumes that a bank produces two outputs in different markets - loans and deposits, and the lending market Lerner Index is calculated as in equation (A4).

Lending Market Lerner Index $=\left(\mathrm{R}_{\mathrm{L}}-\mathrm{R}_{\mathrm{M}}-\mathrm{MC}_{\mathrm{L}}\right) / \mathrm{R}_{\mathrm{L}}$

where $R_{L}$ is the bank lending rate reversely calculated as interest income to gross loan, and $R_{M}$ is the mean value of country-level nominal long-term and short-term interest rate. $\mathrm{MC}_{\mathrm{L}}$ is the lending market marginal cost, calculates as the first-order derivative of the rewritten trans-log cost function containing three input prices and two outputs with respect to lending market output. See full details in Forssbeck and Shehzad (2015, pp.2003). 


\section{Appendix B: Definitions and sources of variables}

Variables

Definition

Original source

Dependent variables

A2F (access to finance Dummy variable coded as one if an SME's total debt is more than a threshold (e.g. $5 \%$ ) of its total assets, zero otherwise.

TDR (total debt ratio) (short-term loans + long-term loans) / total assets.

BvD Amadeus

BvD Amadeus

Main bank variables

Lerner Index

Proxy of bank market power, see appendix A.

Fitch Connect and Bank Focus

Lend'Mkt.Lerner

Proxy of bank market power on lending market, see appendix A.

Fitch Connect and Bank Focus

Firm variables

Firm size

Natural logarithm of firm's total assets in dollars.

BvD Amadeus

Firm age

Firm's real age in years categorised into Start-up (0-3), Young (4-7), Middle (8-12)

BvD Amadeus and Mature $(>=13)$. Or natural logarithm of firm's age plus one.

Cash

Proxy of an SME's cash-richness. Measured as cash \& cash equivalent divided by total assets (without cash).

Tangibility

Proxy of an SME's collateral capability. Measured as fixed tangible assets scaled by total assets.

Profitability

Proxy of an SME's performance. Measured as (EBIT + financial profit/loss)*100\% / total assets.

Liquidity

Proxy of an SME's short-term liquidity position. Measured as (current assets - stock) / current liabilities.

Trade credit

Proxy of the degree of an SME's trade credit usage. Measured as net trade credit scaled by total assts.

Growth opportunity Proxy of an SME's need for finance. Measured as industry-level median sales growth rate or for robustness, industry-level intangible assets to total assets.

Innovation Time invariant binary measure of whether an SME is innovative. Dummy variable coded as one if an SME has ever had a patent or trademark, zero otherwise.

Bank-level controls

Bank size

Natural logarithm of a bank's total assets in thousands of dollars.

Fitch Connect

Bank leverage

Proxy of a bank's leverage and risk level. Measured as (shareholders equity + noncontrolling interests) $* 100 \% /$ total assets.

Bank activity

Measure on how diversified is a bank's operational structure in term of non-traditional business. Measured as total off-balance sheet items / total assets. Or for robustness check, percentage of bank's non-interest income to total income.

DEA efficiency

Proxy of a bank's intermediary efficiency using Data Envelopment Analysis (DEA), see section 3.2.3.

Cost efficiency

Ratio-based proxy for overall bank-level cost efficiency. (total operating expenses / operating revenues)*100\%

BvD Amadeus

BvD Amadeus

BvD Amadeus

BvD Amadeus

BvD Amadeus

BvD Amadeus

BvD Amadeus

\section{Country variables}

HHI Index

Concentration

GDP growth rate

Bank development

Branch growth
Herfindahl-Hirschman index. Measure of country-level banking market concentration, sum of the squared values of each bank's market share (total assets) in a banking market.

Sum of total assets of three (or five) largest banks in a banking market as a share of total banking industry assets.

Proxy of economic condition. Annual growth rate of GDP.

Proxy of the importance of traditional banking industry in credit market and financial development. Calculated as Domestic credit to private sector by banks (\% of GDP).

Growth of the number of physical branches in a country from last year. Proxy of changes of SME's accessibility to physical branching services.
European Central Bank Data Warehouse

Global Financial Development

World Development Indicators

World Development Indicators

European Central Bank Data Warehouse 


\section{References}

Abubakr, S., Esposito, F., 2012. Bank concentration and financial constraints on firm investment in UK. Studies in Economics and Finance 29(1), 11-25.

Agoraki, M. Delis, M., Pasiourasc, F., 2011. Regulations, competition and bank risk-taking in transition countries. Journal of Financial Stability 7, pp 38-48.

Agostino, M., Trivieri, F., 2010. Is banking competition beneficial to SMEs? An empirical study based on Italian data. Small Business Economics 35, 335-355.

Akins, B., Li, L., Ng, J., Rusticus, T., 2016. Bank competition and financial stability: evidence from financial crisis. Journal of Financial and Quantitative Analyses 52(1), 1-28.

Alvarez, R., Bertin M., 2016. Bank competition and firm-level financial constraints in Latin America. Emerging Markets Review 28, 89-104.

Anginer, D., Demirguc-Kunt, A., Zhu, M., 2014. How does competition affect bank systemic risk? Journal of Financial Intermediation 23, 1-26.

Arellano, M., Bover, O., 1995. Another look at the instrumental variable estimation of error-components models. Journal of Econometrics 68, 29-51.

Arellano, M., Bond, S., 1991. Some tests of specification for panel data: Mont Carlo evidence and an application to employment equations. Review of Economic Studies 58(2), 277-297.

Athanasoglou, P., Brissimis, S., Delis, M., 2008. Bank-specific, industry-specific and macroeconomic determinants of bank profitability. Journal of International Financial Markets, Institutions \& Money 18, 121136.

Ayyagari, M., Demirguc-Kunt, A., Maksimovic, V., 2011. Firm innovation in emerging markets: The role of finance, governance, and competition. Journal of Financial and Quantitative Analysis 46(6), 1545-1580.

Ayyagari, M., Juarros, P., Peria M., Singh, S., 2016. Access to finance and job growth: Firm-level evidence across developing countries. World Bank.

Baert, L., Vennet, R., 2008. Bank ownership, firm value and firm capital structure in Europe. Ghent University Working Paper.

Barbiero, F., Brutscher, P., Kolev, A., Popov, A., Wolski, M., 2016. Misallocation of investment in Europe: Debt overhang, credit market distress, or weak demand? European Central Bank.

Baum, C.F., 2006. An introduction to modern econometrics using Stata. StataCorp LP. ISBN-10: 1-59718-013-0.

Beck, T., Demirguc-Kunt, A., Maksimovic, V., 2004. Bank competition and access to finance: international evidence. Journal of Money, Credit and Banking 36(3), 627-648.

Behr, P., Norden L., Felix, N., 2013. Financial constraints of private firms and bank lending behaviour. Journal of Banking \& Finance 37(9), 3472-3485.

Bellucci, A., Borisov, A., Giombini, G., Zazzaro, A., 2015. Collateral and local lending: Testing the lender-based theory. Institute for Applied Economic Research: Working paper No. 119.

Berg, S. A., Kim, M., 1994. Oligopolistic interdependence and the structure of production in banking: An empirical evaluation. Journal of Money, Credit and Banking 26, 309-322.

Berger, A., 1995. The profit-structure relationship in banking: test of market-power and efficient structure hypothesis. Journal of Money, Credit and Banking 27(2), 404-431.

Bikker, J., Bos, J., 2008. Bank performance: a theoretical and empirical framework for the analysis of profitability, competition and efficiency. Oxon: Routledge.

Bikker, J., Shaffer, S., Shaffer, S., 2012. Assessing Competition with the Panzar-Rosse Model: The Role of Scale, Costs, and Equilibrium. The Review of Economics and Statistics 94(4), 1025-1044. 
Blundell, R., Bond, S., 1998. Initial conditions and moment restrictions in dynamic panel data models. Journal of Econometrics 87, 115-143.

Bolt, W., Humphrey, D., 2015. A frontier measure of U.S. banking competition. European Journal of Operational Research 246, 450-461.

Boone, J., 2008. A new way to measure competition. The Economic Journal 118, 1245-1261.

Boot, A., Thakor, A., 2000. Can Relationship Banking Survive Competition? Journal of Finance 55, 679-713.

Bos, J., Kolari, J., Lamoen, R., 2013. Competition and innovation: Evidence from financial services. journal of Banking \& Finance 37, 1590-1601.

Bougheas, S., Mizen, P., Yalcin, C., 2006. Access to external finance: Theory and evidence on the impact of monetary policy and firm-specific characteristics. Journal of Banking \& Finance 30, 199-227.

Boyd, J., De Nicolo, G., 2005. The theory of bank risk taking and competition revisited. Journal of Finance 60, 1329-1343.

Brown, M., Jappelli, T., Pagano, M., 2009. Information sharing and credit: firm-level evidence from transition countries. Journal of Financial Intermediation 18, 151-172.

Bulow, J., Klemperer, P., 2002. Prices and the winner's curse. RAND journal of Economics 33(1), 1-21.

Campello, M., Larrain, M., 2014. Enlarging the contracting space: Collateral menus, access to credit, and economic activity. NBER Working Paper No. 21690.

Carbo-Valverde, S. Rodriguez-Fernandez, F., Udell, G., 2009. Bank market power and SME financing constraints. Review of Finance. Finance 13, 309-340.

Carbo-Valverde, S. Rodriguez-Fernandez, F., Udell, G., 2016. Trade credit, the Financial Crisis, and SME access to finance. Journal of Money, Credit and Banking 48(1), 113-143.

Cetorelli, N., Gambera, M., 2001. Banking market structure, financial dependence and growth: international evidence from industry data. Journal of Finance 56(2), 617-648.

Chodorow-Reich, G., 2014. The Employment Effects of Credit Market Disruptions: Firm-level Evidence from the 2008-09 Financial Crisis. Quarterly Journal of Economics 129(1), 1-59.

Chong, T., Lu, L., Ongena, S., 2013. Does banking competition alleviate or worsen credit constraints faced by small- and medium-sized enterprises? Evidence from China. Journal of Banking \& Finance 37, 3412-3424.

Cipollini, A., Fiordelisi, F., 2012. Economic value, competition and financial distress in the European banking system. Journal of Banking \& Finance 36, 3101-3109.

Claessens, S., Laeven. L., 2004. What drives bank competition? Some international evidence. Journal of Money, Credit and Banking 36(3-2), 563-583.

Daskalakis, N. Balios, D., Dalla, V., 2017. The behaviour of SMEs' capital structure determinants in different macroeconomic states. Journal of Corporate Finance 46, 248-260.

De la Torre, A., Peria, M., Schumukler, S., 2010. Bank involvement with SMEs: Beyond relationship lending. Journal of Banking \& Finance 34, 2280-2293.

Delis, M., Kouretas, G., 2011. Interest rates and bank risk-taking. Journal of Banking \& Finance 35, 840-855.

Demiroglu, C., James, C., Kizilaslan, A., 2012. Bank lending standards and access to lines of credit. Journal of Money, Credit and Banking 44(6), 1063-1089.

Di Patti, E., Dell'Ariccia., 2004. Bank competition and firm creation. Journal of Money, Credit and Banking 36(2), 225-251.

Diamond, D.W., 1991. Monitoring and reputation: the choice between bank loans and privately placed debt. Journal of Political Economy 99, 689-721.

Ding, S., Guariglia, A., Knight, J., 2013. Investment and financing constraints in China: Does working capital management make a difference? Journal of Banking \& Finance 37, 1490-1507. 
Donner, A., 1986. A review of inference procedures for the intraclass correlation coefficient in the one-way random effects model. International Statistical Review 54, 67-82.

Ergungor, O., 2004. Comments on "Bank competition and access to finance: international evidence". Journal of Money, Credit and Banking 36(3), 649-654.

Fazzari, S., Hubbard, G., Peterson, B., 1988. Financing constraints and corporate investment. Brookings Papers on Economic Activity 78, 141-195.

Ferrando, A., Iudice, M., Altomonte, C., Blank, S., Felt, M., Meinen, P., Neugebauer, K., Siedschlag, L., 2015. Assessing the financial and financing conditions of firms in Europe: the financial module in CompNet., European Central Bank, No. 1837.

Fiordelisi, F., Mare, D., 2014. Competition and financial stability in European cooperative banks. Journal of International Money and Finance 45, 1-16.

Forssbeck, J., Shehzad, C., 2015. The conditional effect of market power on bank risk - Cross-country evidence. Review of Finance 19, 1997-2038.

Fu, X., Lin, Y., Molyneux, P., 2014. Bank competition and financial stability in Asia Pacific. Journal of Banking \& Finance 38, 64-77.

Fungacova, Z., Shamshur, A., Weill, L., 2017. Does bank competition reduce cost of credit? Cross-country evidence from Europe. Journal of Banking \& Finance 83, 104-120.

Ghosh, P., Mookherjee, D., and Ray, D., 1999. Credit rationing in developing countries: An overview of the theory. Readings in the theory of Development Economics. Blackwell, London.

Giannetti, M., Ongena, S., 2012. "Lending by example": Direct and indirect effects of foreign banks in emerging markets.” Journal of International Economics 86(1), 167- 180.

Gonzalez, V., Gonzalez, F., 2008. Influence of bank concentration and institutions on capital structure: New international evidence. Journal of Corporate Finance 14, 363-375.

Griffins, L.E., 2002. Evolution and revolution as organizations grow. Harvard Business Review 50(4), 37-46.

Hadlock, C., Pierce, J., 2010. New evidence on measuring financial constraints: moving beyond the KZ index. The Review of Financial Studies 23(5), 1909-1940.

Haltiwanger J., Jarmin, R., Miranda, J., 2013. Who creates jobs? Small vs. large vs. young. Review of Economics and Statistics 95(2), 347-361.

Han, L., Benson, A., 2010. The use and usefulness of financial assistance to UK SMEs. Environment and Planning C: Government and Policy 28(3), 552-566.

Han, L., Fraser, S., Storey, D., 2009. Are good or bad borrowers discouraged from applying for loans? Evidence from US small business credit markets. Journal of Banking \& Finance 33, 415-424.

Han, L., Zhang, S., Greene, F., 2017. Bank market concentration, relationship banking, and small business liquidity. International Small Business journal. Vol. 354, pp. 365-384.

Holmstrom, B., Tirole, J., 1998. Private and public supply of liquidity. Journal of Political Economy 106(1), 140.

Harris, O., Huerta, D., Ngo, T., 2013. The impact of TARP on bank efficiency. Journal of International Financial Markets, Institutions \& Money 24, 85-104.

Ji, Y., Lee, C., 2010. Data Envelopment Analysis. The Stata Journal 10(2), 267-280.

Jimenez, G., Lopez, J., Saurina, J., 2007. How does competition impact bank risk-taking? Federal Reserve Bank of San Francisco. Working Paper 2007-23.

Kalemli-Ozcan, S., Laeven, L., Moreno, D., 2019. Debt overhang, rollover risk and investment in Europe. European Central Bank, No. 2241.

Kick, T., Prieto, E., 2015. Bank risk and competition: Evidence from regional banking markets. Review of Finance $19,1185-1222$. 
Lancaster, T., 2000. The incidental parameter problem since 1948. Journal of Econometrics 95(2), 391-413.

Lapteacru, I., 2014. Do more competitive banks have less market power? The evidence from Central and Eastern Europe. Journal of International Money and Finance 46, 44-60.

Lapteacru, I., 2017. Market power and risk of Central and Eastern European banks: Does more powerful mean safer? Economic Modelling 63, 46-59.

Larrain, B., 2006. Do banks affect the level and composition of industrial volatility? Journal of Finance 61(4), 1827-1925.

Lau, L., 1982. On identifying the degree of competitiveness from industry, price and output data. Economics Letters 10, 93-99.

Leon, F., 2014. Measuring competition in banking: A critical review of methods. Serie Etudes et documents du CERDI.

Leon, F., 2015. Does bank competition alleviate credit constraints in developing countries? Journal of Banking \& Finance 57, 130-142.

Lerner, A. P., 1934. The concept of monopoly and the measurement of monopoly power. The Review of Economic Studies 1(3), 157-175.

Leroy, A., 2014. Competition and the bank lending channel in Eurozone. Journal of International Financial Markets \& Money 31, 296-314.

Leroy, A., Lucotte, Y., 2017. Is there a competition-stability trade-off in European banking? Journal of International Financial Markets, Institutions \& Money 46, 199-215.

Love, I., Peria, M., 2014. How bank competition affects firms' access to finance. The World Bank Economic Review 29(3), 413-448.

Marchenko, Y. V., 2006. Estimating variance components in Stata. Stata Journal 6, 1-21.

Marco, F, D., 2019. Bank lending and European sovereign debt crisis. Journal of Financial and Quantitative Analysis 54(1), 155-182.

Maudos, J., Guevara, F., 2007. The cost of market power in banking: social welfare loss vs. cost inefficiency. Journal of Banking \& Finance 31(7), 2103-2125.

Meslier, C., Tacneng, R., Tarazi, A., 2014. Is bank income diversification beneficial? Evidence from and emerging economy. Journal of International Financial Markets, Institutions \& Money 31, 97-126.

Mudd, S., 2013. Bank structure, relationship lending and small firm access to finance: a cross-country investigation. Journal of Financial Service Research 44, 149-174.

Northcott, C.A., 2004, Competition in banking: a review of literature, Bank of Canada Working Paper, ISSN $1192-5434$

Ongena, S., Sendeniz-Yuncu, I., 2011. Which firms engage small, foreign, or state banks? And who goes Islamic? Evidence from Turkey. Journal of Banking \& Finance, 35, 3213-3224.

Ongena, S., Smith, D.C., 2001. The duration of bank relationships. Journal of Financial Economics 61, 449-475.

Ongena, S., Peydro, J., Horen N., 2015. Shocks Abroad, Pain at Home? Bank-Firm Level Evidence on the International Transmission of Financial Shocks. IMF Economic Review 63(4), 698-750.

Panzar, J., Rosse, J., 1982. Structure, conduct and comparative statistics. Bell Laboratories Economic Discussion Paper No. 248. Bell Labs Statistics Research Department, Murray Hill, NJ.

Panzar, J., Rosse, J., 1987. Testing for ‘monopoly’ equilibrium. Journal of Industrial Economics 35, 443-56.

Perera, A., Ralston, D., Wickramanayake, J., 2014. Impact of off-balance sheet banking on the bank lending channel of monetary transmission: Evidence from South Asia. Journal of International Financial Markets, Institutions \& Money 29, 195-216. 
Petersen, M., Rajan, R., 1995. The effect of credit market competition on lending relationships, Quarterly Journal of Economics 110(2), 407-443.

Phan, H., Daly, K., Akhter, S., 2016. Bank efficiency in emerging Asian countries. Research in International Business and Finance 38, 517-530.

Ratti, R., Lee, S., Seol Y., 2008. Bank concentration and financial constraints on firm-level investment in Europe. Journal of Banking \& Finance 32, 2684-2694.

Roodman, D., 2009. How to do xtabond2: An introduction to difference and system GMM in Stata. Stata Journal 9(1): 86-136.

Ruckes, M., 2004. Bank competition and credit standards. The Review of Financial Studies 17(4), 1073-1102.

Ryan, R., O’Toole, C., McCann, F., 2014. Does bank market power affect SME financing constraints? Journal of Banking \& Finance 49, 495-505.

Siedschlage, I., O’Toole, C., Murphy, G., O’Connell, B., 2014. Access to External Financing and Firm Growth. ESRI: Background Study for the European Competitiveness Report.

Soedarmono, W., Machrouh, F., Tarazi, A., 2013. Bank competition, crisis and risk taking: Evidence from emerging markets in Asia. Journal of International Financial Markets, Institutions \& Money 23, 196-221.

Stein, J., 2002. Information production and capital allocation: decentralized vs. hierarchical firms." Journal of Finance 57, 1891-1921.

Sufi, A., 2009. Bank lines of credit in corporate finance: an empirical analysis. Review of Financial Studies 22(3), 1057-1088.

Tacneng, R., 2014. Local Banking Market Structure and SME Financing Obstacles: Evidence from the Philippines. LAPE Working Paper.

Tan, Y., Floros, C., 2013. Risk, capital and efficiency in Chinese banking. Journal of International Financial Markets, Institutions \& Money 26, 378-393.

Tian, L., Han, L., Mi, B., 2019. Bank competition, information specialization and innovation. Review of Quantitative Finance and Accounting, 1-25.

Turk-Ariss, R., 2010. On the implications of market power in banking: Evidence from developing countries. Journal of Banking \& Finance 34(4), 765-775.

Vatiero M., 2010. The Ordoliberal notion of market power: an institutionalist reassessment. European Competition Journal 6(3), 689-707.

Vigneron, L., Benkraiem, R., Miloudi, A., 2016. How do banking relationships affect financial constraints of SMEs? Université de Valenciennes.

Williams, B., 2016. The impact of non-interest income on bank risk in Australia. Journal of Banking \& Finance 73, 16-37.

Williams, J., 2012. Efficiency and market power in Latin American banking. Journal of Financial Stability 8, 263276.

Windmeijer, F., 2005. A finite sample correction for the variance of linear efficient two-step GMM estimator. Journal of Econometrics 126(1), 25-51.

Yosha, O., 1995. Information disclosure costs and the choice of financing source. Journal of Financial Intermediation 4(1), 3-20.

Zarutskie, R., 2006. Evidence on the effects of bank competition on firm borrowing and investment. Journal of Financial Economics 81(3), 503-537. 
Table 1: Bank, firm and industry distribution

\begin{tabular}{|c|c|c|c|c|c|c|c|c|}
\hline \multicolumn{2}{|c|}{ Banks by Country } & \multirow[b]{2}{*}{ Percent } & \multicolumn{2}{|c|}{ SMEs by Country } & \multicolumn{4}{|c|}{ SMEs by Industry } \\
\hline & Freq. & & & Freq. & Percent & & Freq. & Percent \\
\hline Germany & 1,682 & 48.47 & UK & 18,990 & 23.94 & $G$ & 25,052 & 31.58 \\
\hline France & 293 & 8.44 & France & 16,849 & 21.24 & $\mathrm{C}$ & 19,176 & 24.17 \\
\hline Austria & 286 & 8.24 & Spain & 14,850 & 18.72 & $\mathrm{~F}$ & 7,476 & 9.42 \\
\hline Spain & 229 & 6.6 & Germany & 11,712 & 14.76 & M & 5,817 & 7.33 \\
\hline UK & 218 & 6.28 & Portugal & 2,746 & 3.46 & $\mathrm{~L}$ & 4,869 & 6.14 \\
\hline Poland & 174 & 5.01 & Poland & 2,374 & 2.99 & $\mathrm{~N}$ & 4,232 & 5.33 \\
\hline Portugal & 131 & 3.78 & Hungary & 2,007 & 2.53 & $\mathrm{H}$ & 4,143 & 5.22 \\
\hline Netherlands & 64 & 1.84 & Austria & 1,838 & 2.32 & $\mathrm{~J}$ & 3,273 & 4.13 \\
\hline Ireland & 50 & 1.44 & Greece & 1,714 & 2.16 & $\mathrm{I}$ & 1,632 & 2.06 \\
\hline Croatia & 41 & 1.18 & Netherlands & 1,472 & 1.86 & $\mathrm{D}$ & 1,208 & 1.52 \\
\hline Hungary & 41 & 1.18 & Croatia & 795 & 1.00 & A & 979 & 1.23 \\
\hline Cyprus & 26 & 0.75 & Slovenia & 708 & 0.89 & $\mathrm{R}$ & 811 & 1.02 \\
\hline Latvia & 22 & 0.63 & Ireland & 535 & 0.67 & $\mathrm{~S}$ & 663 & 0.84 \\
\hline Iceland & 21 & 0.61 & Estonia & 502 & 0.63 & $\mathrm{~T}$ & 4 & 0.01 \\
\hline Slovenia & 18 & 0.523 & Lithuania & 488 & 0.62 & & & \\
\hline Malta & 17 & 0.49 & Latvia & 474 & 0.60 & & & \\
\hline Greece & 16 & 0.46 & Malta & 228 & 0.29 & & & \\
\hline Lithuania & 11 & 0.32 & Cyprus & 131 & 0.17 & & & \\
\hline Estonia & 9 & 0.26 & Iceland & 118 & 0.15 & & & \\
\hline
\end{tabular}

Industry codes: G: wholesale and retail trade. C: manufacturing. F: construction. M: professional, scientific and technical activities. L: real estate activities. N: administrative and support service activities. H: transportation and storage. J: information and communication. I: accommodation and food service activities. D: electricity, gas, steam and air conditioning supply. A: agriculture, forestry and fishing. R: arts, entertainment and recreation. S: other service activities. T: activities of households as employers. Other industries are not included in this study. 
Table 2: Dependent variable distributions across countries and years

\begin{tabular}{|c|c|c|c|c|c|c|c|c|c|c|c|c|}
\hline & & 06 & 07 & 08 & 09 & & & 12 & 13 & 14 & 15 & ivg. \\
\hline \multirow[t]{2}{*}{ Austria } & & & & & & & & & & & $6 \%$ & $.5 \%$ \\
\hline & & & & & & & & & & & & \\
\hline \multirow[t]{2}{*}{ Су } & & & & $2.7 \%$ & & & & & & & & $.0 \%$ \\
\hline & & & & & & & & & & & & \\
\hline \multirow[t]{2}{*}{ Ge rmany } & & $\%$ & & & & & & & & & & $1 \%$ \\
\hline & & & & & & & & & & & & $6 \%$ \\
\hline \multirow[t]{2}{*}{ Estonia } & & & & & & & & & & & & $.7 \%$ \\
\hline & & & & & & & & & & & & $8 \%$ \\
\hline \multirow[t]{2}{*}{ Spain } & F & $78.1 \%$ & 78 & $\%$ & & & & & & & $0 \%$ & $.1 \%$ \\
\hline & & & & & & & & & & & & $.0 \%$ \\
\hline \multirow[t]{2}{*}{ France } & & $\%$ & & & & & & & & & & $.0 \%$ \\
\hline & $\mathbf{R}$ & $\%$ & & & & & & & & & & $.5 \%$ \\
\hline \multirow[t]{2}{*}{ UK } & $\mathbf{A 2 F}$ & $69.6 \%$ & & & & & & & & & & $71.2 \%$ \\
\hline & & & & & & & & & & & & $8 \%$ \\
\hline \multirow[t]{2}{*}{ Greece } & & & & & & & & & & & & \\
\hline & & & & & & & & & & & & \\
\hline \multirow[t]{2}{*}{ Croatia } & & & & & & & & & & & & \\
\hline & & & & & & & & & & & & \\
\hline \multirow[t]{2}{*}{ Hungary } & A & & & & & & & & & & & $4 \%$ \\
\hline & & & & & & & & & & & & $2 \%$ \\
\hline \multirow[t]{2}{*}{ Ireland } & $\mathbf{A} 2 \mathrm{~F}$ & $81.8 \%$ & & & & & & & & & & $5 \%$ \\
\hline & & & & & & & & & & & & $2 \%$ \\
\hline \multirow[t]{2}{*}{ Iceland } & $\mathbf{F}$ & $79.5 \%$ & & & & & & & & $2 \%$ & $2 \%$ & $8 \%$ \\
\hline & & & & & & & & & & & & $1 \%$ \\
\hline \multirow[t]{2}{*}{ Lat } & & & & & & & & & & & & \\
\hline & & & & & & & & & & & & \\
\hline \multirow[t]{2}{*}{ Lithuania } & & & & & & & & & & & & \\
\hline & & & & & & & & & & & & \\
\hline \multirow[t]{2}{*}{ Malta } & $\mathbf{A} 2 \mathrm{~F}$ & & & & & & & & & & & \\
\hline & TDR & 21 & & & $\%$ & 20 & & $\%$ & & & & $9.4 \%$ \\
\hline \multirow[t]{2}{*}{ Nethe rland } & $\mathrm{d}: \mathrm{A} 2 \mathrm{~F}$ & $84.0 \%$ & 76 & 75 & $\%$ & 72 & $\%$ & $2 \%$ & $2 \%$ & $5 \%$ & $\%$ & $73.3 \%$ \\
\hline & TDR & $25.1 \%$ & 25 & & & 22 & $\%$ & $\%$ & $\%$ & & $\%$ & $8 \%$ \\
\hline \multirow[t]{2}{*}{ Poland } & & & & & & & & & & & & \\
\hline & TDR & $13.7 \%$ & & & & & & & & & & $14.4 \%$ \\
\hline \multirow[t]{2}{*}{ Portugal } & & $84.2 \%$ & & & & & & & & & & $82.3 \%$ \\
\hline & & & & & & & & & & & & $30.2 \%$ \\
\hline \multirow[t]{2}{*}{ Slovenia } & & $84.5 \%$ & & & & & & $79.4 \%$ & & & & $78.5 \%$ \\
\hline & TDR & $27.0 \%$ & & & & & $28.4 \%$ & $28.4 \%$ & $25.7 \%$ & $23.7 \%$ & $22.4 \%$ & $26.7 \%$ \\
\hline \multirow[t]{2}{*}{ vg. } & & & & & & & & & & & $63.0 \%$ & $05.2 \%$ \\
\hline & TDR & $20.6 \%$ & $21.1 \%$ & $22.3 \%$ & $22.3 \%$ & $21.9 \%$ & $21.8 \%$ & $21.6 \%$ & $21.1 \%$ & $20.5 \%$ & $19.0 \%$ & $21.2^{c}$ \\
\hline
\end{tabular}


Table 3: Dependent variable distribution across industries and years

\begin{tabular}{|c|c|c|c|c|c|c|c|c|c|c|c|c|}
\hline ndustry & & 2006 & 2007 & 2008 & 2009 & 2010 & 2011 & 2012 & 2013 & 2014 & 2015 & Avg. \\
\hline \multirow[t]{2}{*}{ G } & A2F & $64.4 \%$ & $64.1 \%$ & $65.2 \%$ & $65.0 \%$ & $64.0 \%$ & $64.5 \%$ & $64.8 \%$ & $63.8 \%$ & $63.8 \%$ & $62.2 \%$ & $64.2 \%$ \\
\hline & TDR & $17.9 \%$ & $17.8 \%$ & $19.1 \%$ & $18.8 \%$ & $18.4 \%$ & $18.5 \%$ & $18.6 \%$ & $18.0 \%$ & $17.8 \%$ & $16.9 \%$ & $18.2 \%$ \\
\hline \multirow[t]{2}{*}{ C } & $\mathbf{A} 2 \mathbf{F}$ & $68.4 \%$ & $68.9 \%$ & $69.3 \%$ & $68.9 \%$ & $67.9 \%$ & $68.2 \%$ & $68.0 \%$ & $66.7 \%$ & $66.4 \%$ & $65.8 \%$ & $67.8 \%$ \\
\hline & TDR & $19.4 \%$ & $20.2 \%$ & $21.0 \%$ & $20.8 \%$ & $20.1 \%$ & $20.0 \%$ & $19.9 \%$ & $19.3 \%$ & $18.8 \%$ & $18.0 \%$ & $19.7 \%$ \\
\hline \multirow[t]{2}{*}{$\mathbf{F}$} & A2F & $60.0 \%$ & $61.0 \%$ & $62.9 \%$ & $63.2 \%$ & $63.2 \%$ & $62.9 \%$ & $62.2 \%$ & $61.5 \%$ & $60.6 \%$ & $58.0 \%$ & $61.6 \%$ \\
\hline & TDR & $20.7 \%$ & $21.5 \%$ & $23.5 \%$ & $23.4 \%$ & $23.2 \%$ & $22.8 \%$ & $21.7 \%$ & $21.0 \%$ & $19.8 \%$ & $17.2 \%$ & $21.5 \%$ \\
\hline \multirow[t]{2}{*}{$\mathbf{M}$} & A2F & $55.2 \%$ & $54.8 \%$ & $55.1 \%$ & $56.1 \%$ & $56.6 \%$ & $57.3 \%$ & $57.6 \%$ & $56.4 \%$ & $56.1 \%$ & $54.8 \%$ & $56.0 \%$ \\
\hline & TDR & $19.2 \%$ & $19.4 \%$ & $19.6 \%$ & $20.8 \%$ & $21.2 \%$ & $20.9 \%$ & $20.7 \%$ & $20.1 \%$ & $20.2 \%$ & $18.8 \%$ & $20.1 \%$ \\
\hline \multirow[t]{2}{*}{$\mathbf{L}$} & A2F & $76.9 \%$ & $77.6 \%$ & $79.0 \%$ & $78.9 \%$ & $78.1 \%$ & $78.3 \%$ & $77.5 \%$ & $77.6 \%$ & $76.2 \%$ & $72.5 \%$ & $77.3 \%$ \\
\hline & TDR & $35.8 \%$ & $36.9 \%$ & $38.7 \%$ & $38.8 \%$ & $38.2 \%$ & $38.3 \%$ & $37.4 \%$ & $36.9 \%$ & $34.8 \%$ & $30.1 \%$ & $36.6 \%$ \\
\hline \multirow[t]{2}{*}{$\mathbf{N}$} & A2F & $58.3 \%$ & $58.0 \%$ & $60.9 \%$ & $61.2 \%$ & $61.3 \%$ & $61.6 \%$ & $64.0 \%$ & $62.3 \%$ & $61.0 \%$ & $60.0 \%$ & $60.9 \%$ \\
\hline & TDR & $23.3 \%$ & $24.4 \%$ & $25.5 \%$ & $25.8 \%$ & $25.6 \%$ & $25.5 \%$ & $25.9 \%$ & $24.9 \%$ & $24.9 \%$ & $23.8 \%$ & $25.0 \%$ \\
\hline \multirow[t]{2}{*}{$\mathbf{H}$} & $\mathbf{A} 2 \mathrm{~F}$ & $63.7 \%$ & $64.3 \%$ & $64.8 \%$ & $64.4 \%$ & $63.1 \%$ & $63.5 \%$ & $63.5 \%$ & $63.7 \%$ & $62.3 \%$ & $64.4 \%$ & $63.8 \%$ \\
\hline & TDR & $20.0 \%$ & $20.6 \%$ & $21.7 \%$ & $21.6 \%$ & $20.8 \%$ & $21.0 \%$ & $20.9 \%$ & $20.8 \%$ & $19.9 \%$ & $19.5 \%$ & $20.7 \%$ \\
\hline \multirow[t]{2}{*}{$\mathbf{J}$} & $\mathbf{A} 2 \mathrm{~F}$ & $48.7 \%$ & $48.9 \%$ & $50.3 \%$ & $51.0 \%$ & $50.1 \%$ & $48.7 \%$ & $48.9 \%$ & $49.8 \%$ & $50.0 \%$ & $48.2 \%$ & $49.5 \%$ \\
\hline & TDR & $14.5 \%$ & $14.5 \%$ & $15.3 \%$ & $15.3 \%$ & $14.9 \%$ & $14.7 \%$ & $14.9 \%$ & $15.4 \%$ & $15.1 \%$ & $13.2 \%$ & $14.8 \%$ \\
\hline & $\mathbf{A} 2 \mathbf{F}$ & $77.2 \%$ & $78.3 \%$ & $80.8 \%$ & $81.9 \%$ & $81.8 \%$ & $81.3 \%$ & $81.2 \%$ & $79.8 \%$ & $79.5 \%$ & $76.6 \%$ & $79.9 \%$ \\
\hline & TDR & $34.4 \%$ & $34.9 \%$ & $36.0 \%$ & $36.9 \%$ & $37.0 \%$ & $36.8 \%$ & $36.5 \%$ & $35.3 \%$ & $33.5 \%$ & $29.1 \%$ & $35.0 \%$ \\
\hline \multirow[t]{2}{*}{ D } & $\mathbf{A} 2 \mathrm{~F}$ & $69.1 \%$ & $71.2 \%$ & $70.5 \%$ & $71.9 \%$ & $71.2 \%$ & $71.7 \%$ & $72.8 \%$ & $73.7 \%$ & $73.3 \%$ & $70.6 \%$ & $71.6 \%$ \\
\hline & TDR & $29.8 \%$ & $31.5 \%$ & $34.7 \%$ & $36.4 \%$ & $36.1 \%$ & $35.5 \%$ & $34.3 \%$ & $34.7 \%$ & $33.7 \%$ & $33.2 \%$ & $34.0 \%$ \\
\hline \multirow[t]{2}{*}{$\mathbf{A}$} & A2F & $74.0 \%$ & $76.4 \%$ & $79.2 \%$ & $79.1 \%$ & $79.3 \%$ & $79.3 \%$ & $77.7 \%$ & $78.8 \%$ & $78.8 \%$ & $79.1 \%$ & $78.2 \%$ \\
\hline & TDR & $22.3 \%$ & $24.4 \%$ & $27.6 \%$ & $27.0 \%$ & $26.4 \%$ & $25.7 \%$ & $25.4 \%$ & $24.9 \%$ & $24.2 \%$ & $24.3 \%$ & $25.2 \%$ \\
\hline \multirow[t]{2}{*}{$\mathbf{R}$} & $\mathbf{A} 2 \mathrm{~F}$ & $64.3 \%$ & $60.9 \%$ & $63.1 \%$ & $64.5 \%$ & $62.7 \%$ & $64.5 \%$ & $64.9 \%$ & $63.8 \%$ & $61.1 \%$ & $61.0 \%$ & $63.1 \%$ \\
\hline & TDR & $23.3 \%$ & $23.5 \%$ & $22.8 \%$ & $24.2 \%$ & $23.7 \%$ & $24.0 \%$ & $24.1 \%$ & $23.9 \%$ & $23.0 \%$ & $21.8 \%$ & $23.4 \%$ \\
\hline \multirow[t]{2}{*}{$\mathbf{S}$} & $\mathrm{A} 2 \mathrm{~F}$ & $61.4 \%$ & $60.0 \%$ & $62.1 \%$ & $63.7 \%$ & $63.8 \%$ & $60.7 \%$ & $57.1 \%$ & $59.3 \%$ & $58.0 \%$ & $57.3 \%$ & $60.3 \%$ \\
\hline & TDR & $21.3 \%$ & $21.4 \%$ & $21.2 \%$ & $23.4 \%$ & $25.0 \%$ & $22.3 \%$ & $19.9 \%$ & $19.3 \%$ & $18.0 \%$ & $18.2 \%$ & $21.0 \%$ \\
\hline \multirow[t]{2}{*}{ Avg. } & A2F & $64.7 \%$ & $65.0 \%$ & $66.4 \%$ & $66.9 \%$ & $66.4 \%$ & $66.4 \%$ & $66.2 \%$ & $65.9 \%$ & $65.2 \%$ & $63.9 \%$ & $65.7 \%$ \\
\hline & TDR & $23.2 \%$ & $23.9 \%$ & $25.1 \%$ & $25.6 \%$ & $25.4 \%$ & $25.1 \%$ & $24.6 \%$ & $24.2 \%$ & $23.4 \%$ & $21.9 \%$ & $24.2 \%$ \\
\hline
\end{tabular}


Table 4: Lerner index weighted averaged by total assets and HHI

\begin{tabular}{|c|c|c|c|c|c|c|c|c|c|c|c|}
\hline Country & & 2007 & 008 & 2009 & 2010 & 2011 & 2012 & 2013 & 2014 & 2015 & Avg. \\
\hline \multirow[t]{2}{*}{ Austria } & $\mathrm{rn}$ & 0.191 & .146 & 0.244 & 0.266 & 0.224 & 0.230 & 0.207 & 0.252 & 0.246 & 0.223 \\
\hline & & & & & & & & & & & 045 \\
\hline \multirow[t]{2}{*}{ Cyprus } & $\mathrm{Le}$ & & & & & & & & & 82 & 294 \\
\hline & & 0.109 & 2 & 09 & & 03 & 01 & 165 & 45 & 144 & .118 \\
\hline \multirow[t]{2}{*}{ Germany } & & 0.128 & & & & & & & & 03 & 168 \\
\hline & & 0.0 & & 021 & & 32 & 31 & 027 & 30 & 27 & .025 \\
\hline \multirow[t]{2}{*}{ Estonia } & Lerner & 0.357 & & 89 & & 107 & 470 & & & 40 & 428 \\
\hline & & & & & & & & 48 & & 241 & 297 \\
\hline \multirow[t]{2}{*}{ Spain } & Lerner & 0.248 & & 09 & & 0.241 & 26 & 246 & 99 & 312 & .270 \\
\hline & & & & & & & & & & & 060 \\
\hline \multirow[t]{2}{*}{ France } & Ler & 0.137 & & 0.203 & & 0.209 & 0.203 & 219 & 15 & 232 & 194 \\
\hline & & & & & & & & & & & 063 \\
\hline \multirow[t]{2}{*}{ UK } & $\mathrm{L}$ & 0.259 & & 96 & & 60 & 28 & 28 & & 198 & 240 \\
\hline & & & & & & & & & & 43 & 0.047 \\
\hline \multirow[t]{2}{*}{ Greece } & & 0. & & & & & & & & 02 & 215 \\
\hline & & 0 & & & & & & 14 & & 25 & 147 \\
\hline \multirow[t]{2}{*}{ Croatia } & & 0.264 & & 0.272 & 292 & 0.292 & 273 & 272 & & 82 & .265 \\
\hline & & & & & & & & & & & 138 \\
\hline \multirow[t]{2}{*}{ Hungary } & Lerner & 0.281 & & & & & 0.216 & 24 & & 56 & .247 \\
\hline & & 0.0 & & & & & & & & 88 & 085 \\
\hline \multirow[t]{2}{*}{ Irelan } & & & & & & & & & & 87 & 169 \\
\hline & & & & & & & & & & & .066 \\
\hline Iceland & $\begin{array}{c}\text { Lerner } \\
\text { HHI }\end{array}$ & 0.214 & 0.324 & 28 & 32 & 01 & 55 & 06 & 30 & 291 & 311 \\
\hline \multirow[t]{2}{*}{ Latvia } & Ler & & & & & & & & & & 286 \\
\hline & & & & & & & & & & 94 & .180 \\
\hline \multirow[t]{2}{*}{ Lithuania } & Ler & & & & & & & & & 60 & .339 \\
\hline & & & & & & & & & & 03 & 109 \\
\hline \multirow[t]{2}{*}{ Malta } & Lerne & 0.321 & ח & 0.318 & 0.364 & 0.356 & 0.401 & 0.390 & 0.402 & 0.344 & 0.347 \\
\hline & & & & & & & & & & & 133 \\
\hline \multirow[t]{2}{*}{ e the rlands } & Ler & & & & & & & 60 & & 94 & 0.137 \\
\hline & & & & & & & & & & & 0.202 \\
\hline \multirow[t]{2}{*}{ Poland } & Lerner & 0.305 & 0.27 & 0.283 & & 0.339 & 0.320 & 0.331 & 59 & 308 & 0.316 \\
\hline & & 0.0 & & & & 56 & & 59 & 0.066 & 067 & 0.060 \\
\hline \multirow[t]{2}{*}{ Portugal } & & & & & & & & & & & 172 \\
\hline & & & & & & & & & & & .116 \\
\hline \multirow[t]{2}{*}{ Slovenia } & Lerner & 0.242 & & & 0.2 & 0.217 & 0.173 & 0.030 & & 0.302 & 0.213 \\
\hline & HHI & 0.128 & 0.127 & 0.126 & 0.116 & 0.114 & 0.112 & 0.105 & 0.103 & 0.108 & 0.119 \\
\hline
\end{tabular}


Table 5: Descriptive statistics

\begin{tabular}{cccccccc} 
Variables & Obs. & Mean & Median & Std.Dev. & Min. & Max. & Skew. \\
\hline Dependent variable & & & & & & & \\
A2F=1 (5\%) & 530,792 & 0.652 & 1.000 & 0.476 & 0.000 & 1.000 & -0.637 \\
Total debt ratio & 524,370 & 0.213 & 0.134 & 0.234 & 0.000 & 1.000 & 1.191 \\
Main bank variables & & & & & & & \\
Lerner Index & 649,464 & 0.232 & 0.234 & 0.109 & -0.474 & 0.706 & -0.845 \\
Lend'Mkt.Lerner & 646,697 & 0.777 & 0.875 & 0.279 & -0.401 & 1.213 & -1.262 \\
Firm variables & & & & & & & \\
Firm size & 637,099 & 16.394 & 16.322 & 1.295 & 6.087 & 25.276 & -0.198 \\
Firm age & 744,746 & 3.530 & 4.000 & 0.884 & 1.000 & 4.000 & -1.755 \\
Cash & 605,870 & 0.170 & 0.054 & 0.313 & 0.000 & 3.000 & 3.970 \\
Tangibility & 622,936 & 0.219 & 0.121 & 0.247 & 0.000 & 1.000 & 1.371 \\
Profitability & 580,605 & 5.756 & 4.132 & 13.422 & -99.782 & 100.000 & -0.031 \\
Liquidity & 607,586 & 1.987 & 1.053 & 4.883 & 0.001 & 85.000 & 9.287 \\
Trade credit & 589,604 & -0.068 & -0.034 & 0.192 & -0.717 & 0.552 & -0.241 \\
Growth Opp. & 692,531 & 0.011 & 0.000 & 0.089 & -0.167 & 0.254 & 1.170 \\
Innovation & 694,368 & 0.213 & 0.000 & 0.410 & 0.000 & 1.000 & 1.400 \\
Bank-level controls & & & & & & & \\
Bank size & 661,291 & 18.971 & 19.316 & 2.140 & 8.400 & 21.843 & -0.538 \\
Bank leverage & 661,009 & 0.060 & 0.051 & 0.034 & -0.302 & 0.616 & 1.204 \\
Bank activity & 627,829 & 0.183 & 0.172 & 0.135 & 0.000 & 1.997 & 6.051 \\
DEA efficiency & 640,101 & 0.631 & 0.611 & 0.142 & 0.252 & 1.000 & 0.615 \\
Cost efficiency & 659,230 & 0.644 & 0.634 & 0.163 & 0.017 & 1.998 & 1.467 \\
Country variables & & & & & & & \\
HHI index & 688,841 & 0.064 & 0.055 & 0.039 & 0.018 & 0.034 & 2.712 \\
Concentration-3 & 608,028 & 67.398 & 66.016 & 11.218 & 38.562 & 100.000 & 0.567 \\
GDP Growth rate & 694,368 & 0.738 & 1.313 & 2.668 & -14.814 & 26.276 & -0.377 \\
B'importance & 693,458 & 122.807 & 114.774 & 41.922 & 36.077 & 253.458 & 0.172 \\
Branch growth & 688,067 & -0.019 & -0.016 & 0.039 & -0.289 & 0.372 & 0.033 \\
\hline
\end{tabular}

Bank data are from the matched dataset, not the Bank-only dataset, hence duplicated observations are included. Statistics cover maximum period (start from 06 for firm data, 07 for banks and 05 for country variables). 
Table 6: Main estimations

\begin{tabular}{|c|c|c|c|c|c|c|c|}
\hline & Model 1 & Model 2 & $\underline{\text { Model } 3}$ & Model 4 & $\underline{\text { Model } 5}$ & $\underline{\text { Model } 6}$ & $\underline{\text { Model } 7}$ \\
\hline Dependent variable: & \multicolumn{3}{|c|}{$\overline{\text { Access }}$ to finance $(\mathrm{A} 2 \mathrm{~F}, \overline{5 \%)}$} & \multicolumn{4}{|c|}{$\overline{\text { Total debt ratio (TDR) }}$} \\
\hline Main regressors & \multicolumn{4}{|c|}{ Lend'Mkt Lerner } & \multicolumn{3}{|c|}{ Lend'Mkt Lerne } \\
\hline Lerner Index & $\begin{array}{c}-\mathbf{0 . 4 1 1 9} * * * \\
(0.0653) \\
\end{array}$ & $\begin{array}{c}-\mathbf{- 0 . 1 3 9 8} * * * \\
(0.0531) \\
\end{array}$ & $\begin{array}{c}-\mathbf{0 . 3 6 2 2} * * * \\
(0.0194) \\
\end{array}$ & $\begin{array}{c}-\mathbf{- 0 . 0 0 9 6} * * * \\
(0.003) \\
\end{array}$ & $\begin{array}{c}-\mathbf{0 . 0 1 4 3} * * * \\
(0.0031) \\
\end{array}$ & $\begin{array}{c}-\mathbf{0 . 0 2 7 8} * * * \\
(0.0039) \\
\end{array}$ & $\begin{array}{c}-\mathbf{0 . 0 1 6 8} * * * * \\
(0.0014) \\
\end{array}$ \\
\hline \multicolumn{8}{|l|}{ Firm \& industry controls } \\
\hline Firm size & $\begin{array}{c}0.2716 * * * \\
(-0.009)\end{array}$ & $\begin{array}{c}0.2923 * * * \\
(0.0084)\end{array}$ & $\begin{array}{c}0.3014 * * * \\
(0.0084)\end{array}$ & $\begin{array}{c}0.04903 * * * \\
(0.0005)\end{array}$ & $\begin{array}{c}0.0486 * * * \\
(0.0007)\end{array}$ & $\begin{array}{c}0.0481 * * * \\
(0.0015)\end{array}$ & $\begin{array}{c}0.0472 * * * \\
(0.0015)\end{array}$ \\
\hline Firm age & $\begin{array}{c}-0.035 * * * \\
(0.0106)\end{array}$ & $\begin{array}{c}-0.0638 * * * \\
(0.0095)\end{array}$ & $\begin{array}{c}-0.0240 * * \\
(0.0097)\end{array}$ & $\begin{array}{c}-00150 * * * \\
(0.0005)\end{array}$ & $\begin{array}{c}-0.0082 * * * \\
(0.0006)\end{array}$ & & \\
\hline Cash-richness & $\begin{array}{c}-0.0350 * * * \\
(0.0106)\end{array}$ & $\begin{array}{c}-1.1695 * * * \\
(0.2175)\end{array}$ & $\begin{array}{c}-1.1640 * * * \\
(0.2174)\end{array}$ & $\begin{array}{c}-0.0418 * * * \\
(0.0011)\end{array}$ & $\begin{array}{c}-02579 * * * \\
(0.0011)\end{array}$ & $\begin{array}{c}-0.0381 * * * \\
(0.0017)\end{array}$ & $\begin{array}{c}-0.0381 * * * * \\
(0.0017)\end{array}$ \\
\hline Tangibility & $\begin{array}{c}2.7216 * * * \\
(0.0419)\end{array}$ & $\begin{array}{c}2.6073 * * * \\
(0.0382)\end{array}$ & $\begin{array}{c}2.5479 * * * \\
(0.0382)\end{array}$ & $\begin{array}{c}0.1607 * * * \\
(0.002)\end{array}$ & $\begin{array}{c}0.1404 * * * \\
(0.0024)\end{array}$ & $\begin{array}{c}0.1215^{* * *} \\
(0.0048)\end{array}$ & $\begin{array}{c}0.1201 * * * \\
(0.0048)\end{array}$ \\
\hline Profitability & $\begin{array}{c}-0.0146 * * * \\
(0.0004)\end{array}$ & $\begin{array}{c}-0.0141^{* * * *} \\
(0.0004)\end{array}$ & $\begin{array}{c}-0.0144 * * * \\
(0.0004)\end{array}$ & & & & \\
\hline Liquidity & $\begin{array}{c}-0.0385^{* * * *} \\
(0.0015)\end{array}$ & $\begin{array}{c}-0.0354 * * * \\
(0.0013)\end{array}$ & $\begin{array}{c}-0.3521 * * * \\
(0.0013)\end{array}$ & $\begin{array}{c}-0.0006^{* * * *} \\
(0.0001)\end{array}$ & $\begin{array}{c}-0.0002 * * \\
(0.0001)\end{array}$ & $\begin{array}{c}-0.0002 * * \\
(0.0001)\end{array}$ & $\begin{array}{c}-0.0002 * * \\
(0.0001)\end{array}$ \\
\hline Trade Credit & $\begin{array}{c}-0.8745^{* * *} \\
(0.0446)\end{array}$ & $\begin{array}{c}-0.8222 * * * \\
(0.0401)\end{array}$ & $\begin{array}{c}-0.8546 * * * \\
(0.0401)\end{array}$ & $\begin{array}{c}-0.8506 * * * \\
(0.0019)\end{array}$ & $\begin{array}{c}-0.1086 * * * \\
(0.0021)\end{array}$ & $\begin{array}{c}-0.1567 * * * \\
(0.0049)\end{array}$ & $\begin{array}{c}-0.1564 * * * * \\
(0.0049)\end{array}$ \\
\hline Innovation & & & & $\begin{array}{c}-0.0194 * * * \\
(0.0019)\end{array}$ & & & \\
\hline Growth Opportunity & $\begin{array}{c}0.1358 * * * \\
(0.0521)\end{array}$ & $\begin{array}{c}0.1962 * * * \\
(0.051)\end{array}$ & $\begin{array}{c}0.2255^{* * *} * \\
(0.0493)\end{array}$ & $\begin{array}{c}0.0959 * * * \\
(0.0053)\end{array}$ & $\begin{array}{c}0.0818^{* * *} \\
(0.006)\end{array}$ & $\begin{array}{c}0.0712 * * * \\
(0.0114)\end{array}$ & $\begin{array}{c}0.0666 * * * \\
(0.0114)\end{array}$ \\
\hline \multicolumn{8}{|l|}{ Country-level controls } \\
\hline HHI index & $\begin{array}{c}3.4264 * * * \\
(0.2794)\end{array}$ & & & $\begin{array}{c}0.0778 * * * \\
(0.0202)\end{array}$ & $\begin{array}{c}0.0709 * * * \\
(0.0206)\end{array}$ & & \\
\hline GDP growth rate & $\begin{array}{c}0.0243 * * * \\
(0.002)\end{array}$ & $\begin{array}{c}0.0013 \\
(0.0017)\end{array}$ & $\begin{array}{c}-0.0782 * * * \\
(0.0017)\end{array}$ & $\begin{array}{c}0.0002 \\
(0.0001)\end{array}$ & $\begin{array}{l}0.0003 * \\
(0.0001)\end{array}$ & $\begin{array}{c}0.0003 * * \\
(0.0002)\end{array}$ & $\begin{array}{c}0.0002 * * \\
(0.0001)\end{array}$ \\
\hline Bank importance & $\begin{array}{c}0.0147 * * * \\
(0.0003)\end{array}$ & $\begin{array}{c}0.0115^{* * *} \\
(0.0003)\end{array}$ & $\begin{array}{c}0.0114 * * * \\
(0.0002)\end{array}$ & $\begin{array}{c}0.0002^{* * * *} \\
(0.0000)\end{array}$ & $\begin{array}{c}0.0003 * * * \\
(0.0000)\end{array}$ & $\begin{array}{c}0.0002 * * * \\
(0.0000)\end{array}$ & $\begin{array}{c}0.0004 * * * \\
(0.0000)\end{array}$ \\
\hline Branch growth & $\begin{array}{c}0.0451 * * * \\
(0.1485)\end{array}$ & $\begin{array}{c}0.3905^{* * *} \\
(0.1239)\end{array}$ & $\begin{array}{c}-0.2826 * * \\
(0.1290)\end{array}$ & $\begin{array}{c}0.0099 \\
(0.0069)\end{array}$ & $\begin{array}{l}0.0121 * \\
(0.0069)\end{array}$ & $\begin{array}{c}0.0216 * * * \\
(0.0072)\end{array}$ & $\begin{array}{c}0.0437 * * * \\
(0.0071)\end{array}$ \\
\hline \multicolumn{8}{|l|}{ Bank-level variables } \\
\hline Bank size & $\begin{array}{c}-0.1823 * * * \\
(0.0068)\end{array}$ & & & $\begin{array}{c}-0.0080 * * * \\
(0.0004)\end{array}$ & $\begin{array}{c}0.0049 * * * \\
(0.0014)\end{array}$ & & \\
\hline Bank leverage & $\begin{array}{c}-0.7799 * * * \\
(0.2557)\end{array}$ & & & $\begin{array}{c}-0.0494 * * * \\
(0.0109)\end{array}$ & $\begin{array}{c}-0.0448 * * * \\
(0.0115)\end{array}$ & & \\
\hline Bank activity & $\begin{array}{c}-0.0959 * * \\
(0.0385)\end{array}$ & $\begin{array}{c}-0.1904 * * * \\
(0.3595)\end{array}$ & $\begin{array}{c}-0.2149 * * * \\
(0.0358)\end{array}$ & $\begin{array}{c}-0.0113 * * * \\
(0.0019)\end{array}$ & $\begin{array}{c}-0.0069 * * * \\
(0.0019)\end{array}$ & $\begin{array}{c}-0.0093 * * * \\
(0.0024)\end{array}$ & $\begin{array}{c}-0.0134 * * * \\
(0.0023)\end{array}$ \\
\hline Bank DEA efficiency & $\begin{array}{c}0.4859 * * * \\
(0.0671)\end{array}$ & $\begin{array}{c}0.1651 * * * \\
(0.053)\end{array}$ & $\begin{array}{c}0.1004 * * \\
(0.0481)\end{array}$ & $\begin{array}{c}0.0081 * * \\
(0.0032)\end{array}$ & $\begin{array}{c}0.0105^{* * *} \\
(0.0033)\end{array}$ & $\begin{array}{c}0.0178 * * * \\
(0.0041)\end{array}$ & $\begin{array}{c}0.0098 * * * \\
(0.0032)\end{array}$ \\
\hline Observations & 322,256 & 352,640 & 352,731 & 359,633 & 359,633 & 366,060 & 366,116 \\
\hline Groups & 62,952 & 63,432 & 63,433 & 65,177 & 65,177 & 65,769 & 65,770 \\
\hline Estimator & RE-PP & RE-PP & RE-PP & RE MLE & $\mathrm{FE}$ & $\mathrm{FE}$ & $\mathrm{FE}$ \\
\hline $\mathrm{R}^{2}$ & $45.24 \%$ & $38.91 \%$ & $38.98 \%$ & N/A & $80.63 \%$ & $80.52 \%$ & $80.49 \%$ \\
\hline
\end{tabular}

*,** and *** respectively represents significance at $10 \%, 5 \%$ and $1 \%$ level, respectively. Constants are added but not reported. All country-level variables are one-year lagged to tolerate response lag of SMEs towards economic fluctuations (Leon, 2015), firm liquidity, profitability and industry-level growth opportunity are also one-year lagged to optimally correspond to their controlling effects. RE-PP, RE MLE and FE stand for random-effects panel Probit estimator, random-effects maximum likelihood estimator and fixed-effects estimator. Because there is no common method to measure the goodness-of-fit of a panel-structured Probit/Logit model, our calculation follows Stata guidance that we use a scaling measure that compares the log-likelihood value of model with the log-likelihood of the same model, but all variables in addition to constant are excluded, the principal is that log-likelihood would be zero when the model is perfectly fit. Results do not change if Models $1-3$ are estimated using random-effects panel logit estimator. For the panel data Models (4 -7), standard errors are clustered at firm level, results still hold if it is clustered at industry or country level. The R-squared (adjusted- $\mathrm{R}^{2}$ ) for FE models include variations captured by firm fixed-effects. In the RE MLE Model (4) we include country, industry and legal-form dummy variables in the model and results still hold if dummy variables are not included. 
Table 7: Equation one robustness tests

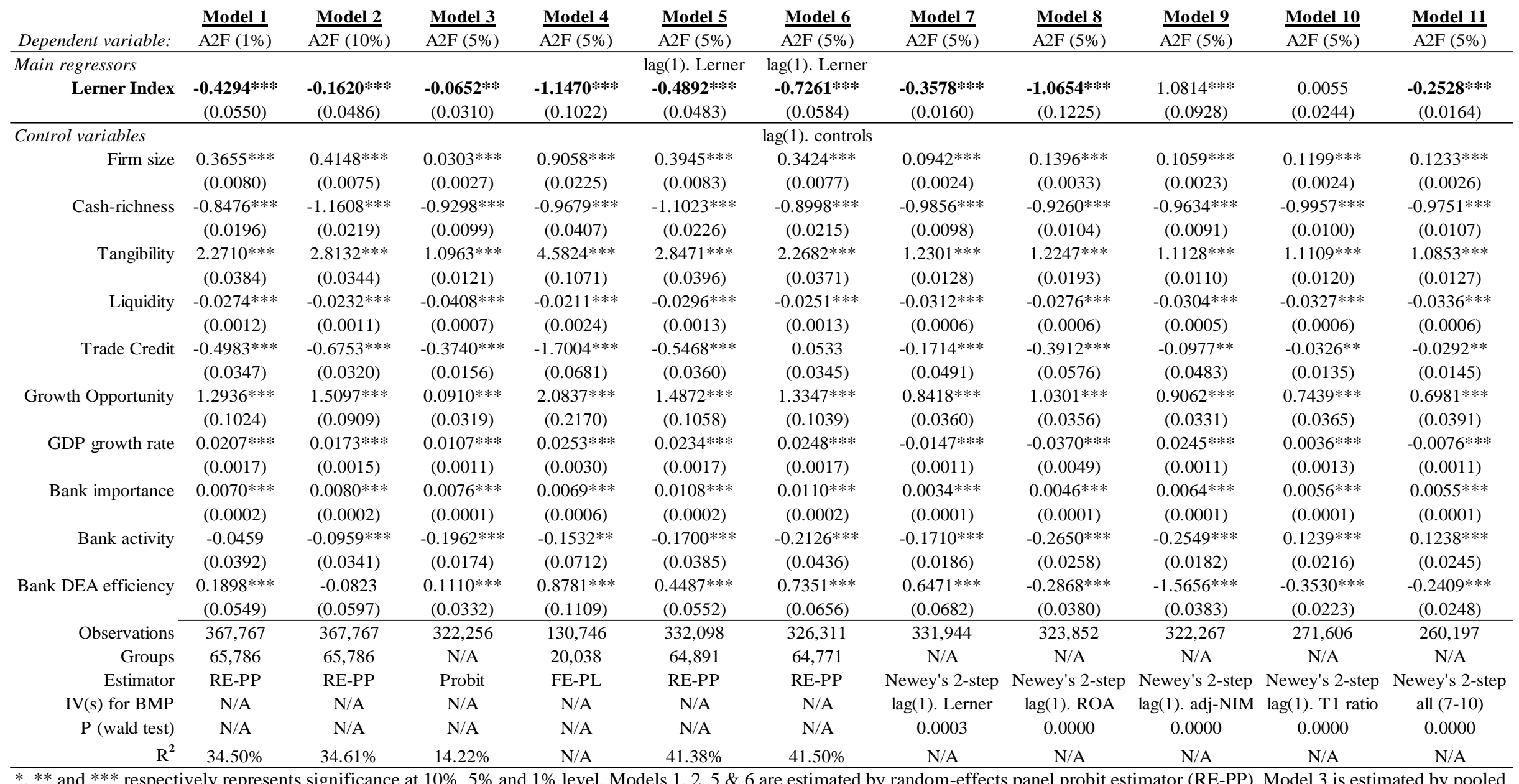
2odels 7 to 11 adopt instrumental variable estimation techn pooled Newey's two-step minimum chi-squared estimator (Newey, 1987). The row "Instruments for Bank Market Power variable" (IVs for BMP) lists the instruments selected in each IV-style regression, followed by the p-values of Wald test of exogeneity. Other notes are same as above (Table 6). 
Table 8: Equation two robustness tests

$\underline{\text { Model } 1} \quad \underline{\text { Model } 2} \quad \underline{\text { Model 3 }} \quad \underline{\text { Model 4 }} \quad \underline{\text { Model 5 }} \quad \underline{\text { Model 6 }} \quad \underline{\text { Model 7 }} \quad \underline{\text { Model } 8} \quad \underline{\text { Model 9 }}$

\begin{tabular}{|c|c|c|c|c|c|c|c|c|c|}
\hline Dependent variable: & $\operatorname{TDR}(>1 \%$ assets $)$ & TDR( $>5 \%$ asse & 6 assets) & TDR & TDR growth rate & Debt growth rate & TDR industry diff. & $\operatorname{diff(1)~TDR}$ & TDR \\
\hline Main regressors & & & & & & & & $\operatorname{diff}(1)$ Lerner & \\
\hline Lerner Index & $\begin{array}{c}-\mathbf{0 . 0 2 1 0} * * * \\
(0.0040) \\
\end{array}$ & $\begin{array}{c}\mathbf{- 0 . 0 1 9 3} * * * \\
(0.0043) \\
\end{array}$ & $\begin{array}{c}-\mathbf{- 0 . 0 1 6 6}^{* * * *} \\
(0.0045) \\
\end{array}$ & $\begin{array}{c}-\mathbf{0 . 0 1 7 6} * * * \\
(0.0027) \\
\end{array}$ & $\begin{array}{c}-\mathbf{0 . 0 9 9 3} * * * \\
(0.0162) \\
\end{array}$ & $\begin{array}{c}-\mathbf{- 0 . 1 8 9 9} * * * \\
(0.0174) \\
\end{array}$ & $\begin{array}{c}\mathbf{- 0 . 0 2 7 4} * * * \\
(0.0032) \\
\end{array}$ & $\begin{array}{c}-\mathbf{- 0 . 0 0 9 7} * * * \\
(0.0018) \\
\end{array}$ & $\begin{array}{c}-\mathbf{- 0 . 0 3 0 6} * * * \\
(0.0035) \\
\end{array}$ \\
\hline Control variables & & & & & & & & $\operatorname{diff}(1)$ controls & + Bank dummies \\
\hline Firm size & $\begin{array}{c}0.0397 * * * \\
(0.0019)\end{array}$ & $\begin{array}{c}0.0377 * * * \\
(0.0019)\end{array}$ & $\begin{array}{c}0.0336 * * * \\
(0.0021)\end{array}$ & $\begin{array}{c}0.0474 * * * \\
(0.0014)\end{array}$ & $\begin{array}{c}0.0609 * * * \\
(0.0053)\end{array}$ & $\begin{array}{c}0.3045^{* * *} \\
(0.0060)\end{array}$ & $\begin{array}{c}0.0425 * * * \\
(0.0013)\end{array}$ & $\begin{array}{c}0.0120 * * * \\
(0.0013)\end{array}$ & $\begin{array}{c}0.0468 * * * \\
(0.0009)\end{array}$ \\
\hline Cash-richness & $\begin{array}{c}-0.0390 * * * \\
(0.0029)\end{array}$ & $\begin{array}{c}-0.0379 * * * \\
(0.0036)\end{array}$ & $\begin{array}{c}-0.0343 * * * \\
(0.0043)\end{array}$ & $\begin{array}{c}-0.0119 * * * \\
(0.0014)\end{array}$ & $\begin{array}{c}-0.1186 * * * \\
(0.0117)\end{array}$ & $\begin{array}{c}-0.0721 * * * \\
(0.0117)\end{array}$ & $\begin{array}{c}-0.0244 * * * \\
(0.0016)\end{array}$ & $\begin{array}{c}-0.0060 * * * \\
(0.0011)\end{array}$ & $\begin{array}{c}-0.0424 * * * \\
(0.0015)\end{array}$ \\
\hline Tangibility & $\begin{array}{c}0.1430 * * * \\
(0.0052)\end{array}$ & $\begin{array}{c}0.1259 * * * \\
(0.0053)\end{array}$ & $\begin{array}{c}0.1060 * * * \\
(0.0053)\end{array}$ & $\begin{array}{c}0.1396 * * * \\
(0.0044)\end{array}$ & $\begin{array}{c}0.3280^{* * *} \\
(0.0144)\end{array}$ & $\begin{array}{c}0.1788 * * * \\
(0.0148)\end{array}$ & $\begin{array}{c}0.1518 * * * \\
(0.0047)\end{array}$ & $\begin{array}{c}0.0406 * * * \\
(0.0039)\end{array}$ & $\begin{array}{c}0.1673 * * * \\
(0.0037)\end{array}$ \\
\hline Liquidity & $\begin{array}{c}-0.0003 * * \\
(0.0001)\end{array}$ & $\begin{array}{l}-0.0001 \\
(0.0001)\end{array}$ & $\begin{array}{l}-0.0001 \\
(0.0001)\end{array}$ & $\begin{array}{c}-0.0009 * * * \\
(0.0001)\end{array}$ & $\begin{array}{c}-0.0013 * * * \\
(0.0005)\end{array}$ & $\begin{array}{l}-0.0009 * \\
(0.0005)\end{array}$ & $\begin{array}{c}-0.0004 * * * \\
(0.0001)\end{array}$ & $\begin{array}{c}0.0001 \\
(0.0001)\end{array}$ & $\begin{array}{c}-0.0006 * * * \\
(0.0001)\end{array}$ \\
\hline Trade Credit & $\begin{array}{c}-0.1168 * * * \\
(0.0041)\end{array}$ & $\begin{array}{c}-0.1254 * * * \\
(0.0045)\end{array}$ & $\begin{array}{c}-0.1313 * * * \\
(0.0050)\end{array}$ & $\begin{array}{c}-0.1092 * * * \\
(0.0028)\end{array}$ & $\begin{array}{c}-0.3251 * * * \\
(0.0165)\end{array}$ & $\begin{array}{c}-0.2742 * * * \\
(0.0170)\end{array}$ & $\begin{array}{c}-0.0940 * * * \\
(0.0031)\end{array}$ & $\begin{array}{c}-0.0941 * * * \\
(0.0032)\end{array}$ & $\begin{array}{c}-0.0782 * * * \\
(0.0029)\end{array}$ \\
\hline Growth Opportunity & $\begin{array}{c}0.0838 * * * \\
(0.0128)\end{array}$ & $\begin{array}{c}0.0726 * * * \\
(0.0133)\end{array}$ & $\begin{array}{c}0.0599 * * * \\
(0.0141)\end{array}$ & $\begin{array}{l}-0.0131 \\
(0.0101)\end{array}$ & $\begin{array}{c}-0.0297 \\
(0.0419)\end{array}$ & $\begin{array}{c}0.1118 * * \\
(0.0468)\end{array}$ & $\begin{array}{c}0.0807 * * * \\
(0.0100)\end{array}$ & $\begin{array}{l}-0.0038 \\
(0.0099)\end{array}$ & $\begin{array}{c}0.0957 * * * \\
(0.0092)\end{array}$ \\
\hline GDP growth rate & $\begin{array}{c}0.0010 * * * \\
(0.0001)\end{array}$ & $\begin{array}{c}0.0011 * * * \\
(0.0001)\end{array}$ & $\begin{array}{c}0.0010^{* * * *} \\
(0.0001)\end{array}$ & $\begin{array}{c}0.0006^{* * * *} \\
(0.0001)\end{array}$ & $\begin{array}{c}0.0072 * * * \\
(0.0005)\end{array}$ & $\begin{array}{c}0.0160 * * * \\
(0.0005)\end{array}$ & $\begin{array}{c}0.0008 * * * \\
(0.0001)\end{array}$ & $\begin{array}{c}-0.0001 * \\
(0.0001)\end{array}$ & $\begin{array}{c}0.0008^{* * * *} \\
(0.0001)\end{array}$ \\
\hline Bank importance & $\begin{array}{c}0.0007 * * * \\
(0.0000)\end{array}$ & $\begin{array}{c}0.0007 * * * \\
(0.0000)\end{array}$ & $\begin{array}{c}0.0006^{* * * *} \\
(0.0000)\end{array}$ & $\begin{array}{c}0.0006^{* * *} \\
(0.0000)\end{array}$ & $\begin{array}{c}0.0009 * * * \\
(0.0001)\end{array}$ & $\begin{array}{c}0.0022 * * * \\
(0.0001)\end{array}$ & $\begin{array}{c}0.0005^{* * *} * \\
(0.0000)\end{array}$ & $\begin{array}{c}0.0006 * * * \\
(0.0000)\end{array}$ & $\begin{array}{c}0.0005^{* * * *} \\
(0.0000)\end{array}$ \\
\hline Bank activity & $\begin{array}{c}-0.0078 * * * \\
(0.0027)\end{array}$ & $\begin{array}{c}-0.0068 * * \\
(0.0028)\end{array}$ & $\begin{array}{c}-0.0076^{* *} \\
(0.0030)\end{array}$ & $\begin{array}{c}-0.0042 * * * \\
(0.0016)\end{array}$ & $\begin{array}{l}-0.0028 \\
(0.0097)\end{array}$ & $\begin{array}{l}-0.0038 \\
(0.0106)\end{array}$ & $\begin{array}{c}-0.0039 * \\
(0.0022)\end{array}$ & $\begin{array}{c}-0.0035^{* *} \\
(0.0015)\end{array}$ & $\begin{array}{c}-0.0067 * * * \\
(0.0024)\end{array}$ \\
\hline Bank DEA efficiency & $\begin{array}{c}0.0316^{* * *} * \\
(0.0045)\end{array}$ & $\begin{array}{c}0.0336^{* * * *} \\
(0.0048)\end{array}$ & $\begin{array}{c}0.0319 * * * \\
(0.0051) \\
\end{array}$ & $\begin{array}{c}0.0093 * * * \\
(0.0031)\end{array}$ & $\begin{array}{c}0.1017 * * * \\
(0.0192) \\
\end{array}$ & $\begin{array}{c}0.2859 * * * \\
(0.0204)\end{array}$ & $\begin{array}{c}0.0299 * * * \\
(0.0036) \\
\end{array}$ & $\begin{array}{c}0.0089 * * * \\
(0.0029)\end{array}$ & $\begin{array}{c}0.0324 * * * \\
(0.0039) \\
\end{array}$ \\
\hline Observations & 278,128 & 239,227 & 204,326 & 279,473 & 287,214 & 287,230 & 331,391 & 297,991 & 366060 \\
\hline Groups & 56,655 & 51,897 & 46,870 & N/A & 57,074 & 57,055 & 61,953 & 61,207 & 65769 \\
\hline Estimator & $\mathrm{FE}$ & $\mathrm{FE}$ & $\mathrm{FE}$ & $\mathrm{PW} \& \mathrm{CO}$ & $\mathrm{FE}$ & $\mathrm{FE}$ & $\mathrm{FE}$ & $\mathrm{FE}$ & RE MLE \\
\hline $\mathrm{R} 2$ & $80.44 \%$ & $79.47 \%$ & $78.35 \%$ & $3.69 \%$ & $20.35 \%$ & $21.99 \%$ & $79.50 \%$ & $81.96 \%$ & N/A \\
\hline
\end{tabular}
$*, * *$ and $* * *$ respectively represents significance at $10 \%, 5 \%$ and $1 \%$ level. PW\&CO denotes Prais-Winsten and Cochrane-Orcutt estimator (Model 4). The standard errors for all fixed-effects
(FE) models are clustered at firm-level, although results do not change if clustered at country or industry level. Model 8 re-specifies the baseline model in a form that transforms both dependent and independent variables into their-one-year difference to capture the effects of real change of explanatory variables on explained variables. Model 9 is estimated by random-effects maximumlikelihood estimator (RE-MLE) to allow the inclusion of bank-level dummy variables that capture unobservable individual bank-level characteristics. Other notes are same as above (Table 6). 
Table 8: Equation two robustness tests (continued)

\begin{tabular}{|c|c|c|c|c|c|c|c|c|c|c|}
\hline Dependent variable: & $\frac{\text { Model 10 }}{\text { TDR }}$ & $\frac{\text { Model 11 }}{\text { TDR }}$ & $\frac{\text { Model 12 }}{\text { TDR }}$ & $\frac{\text { Model } 13}{\text { TDR }}$ & $\frac{\text { Model } 14}{\text { TDR }}$ & $\frac{\text { Model } 15}{\text { TDR }}$ & $\frac{\text { Model 16 }}{\text { TDR }}$ & & $\frac{\text { Model } 17}{\text { TDR }}$ & $\frac{\text { Model } 18}{\text { TDR }}$ \\
\hline $\begin{array}{l}\text { Main regressors } \\
\text { Lerner Index }\end{array}$ & $\begin{array}{c}\text { lag(1). Lerner } \\
\mathbf{- 0 . 0 1 2 3}^{*} * * * \\
(0.0029) \\
\end{array}$ & $\begin{array}{c}\operatorname{lag}(1) . \text { Lerner } \\
\mathbf{- 0 . 0 3 8 3}^{* * * *} \\
(0.0036) \\
\end{array}$ & $\begin{array}{c}-\mathbf{- 0 . 0 6 9 9} * * * * \\
(0.0145) \\
\end{array}$ & $\begin{array}{c}-\mathbf{- 0 . 0 5 6 7 * * * *} \\
(0.0102) \\
\end{array}$ & $\begin{array}{c}-\mathbf{0 . 2 6 0 3} * * * \\
(0.0694) \\
\end{array}$ & $\begin{array}{c}-\mathbf{0 . 0 3 9 5} * * * \\
(0.0151) \\
\end{array}$ & $\begin{array}{c}-\mathbf{0 . 0 9 7 2} * * * \\
(0.0070) \\
\end{array}$ & & $\begin{array}{c}\mathbf{- 0 . 0 4 3 7 * * * *} \\
(0.0145) \\
\end{array}$ & $\begin{array}{c}-\mathbf{0 . 0 1 1 6} * * * * \\
(0.0025) \\
\end{array}$ \\
\hline $\begin{array}{r}\text { Dynamic variable } \\
\text { lag(1).TDR }\end{array}$ & & & & & & & & & $\begin{array}{c}0.5683 * * \\
(0.2731) \\
\end{array}$ & $\begin{array}{c}0.4967 * * * \\
(0.0271) \\
\end{array}$ \\
\hline $\begin{array}{l}\text { Control variables } \\
\text { Firm size }\end{array}$ & $\begin{array}{c}0.0439 * * * \\
(0.0016)\end{array}$ & $\begin{array}{c}\text { lag(1). Controls } \\
0.0317 * * * \\
(0.0013)\end{array}$ & $\begin{array}{l}0.0475^{* * *} \\
(0.0014)\end{array}$ & $\begin{array}{c}0.0500^{* * *} * \\
(0.0012)\end{array}$ & $\begin{array}{c}0.0693 * * * \\
(0.0066)\end{array}$ & $\begin{array}{c}0.0498 * * * \\
(0.0016)\end{array}$ & $\begin{array}{c}0.0515^{* * * *} \\
(0.0017)\end{array}$ & & $\begin{array}{l}0.0427 * * * \\
(0.0025)\end{array}$ & $\begin{array}{c}0.0085^{* * *} * \\
(0.0006)\end{array}$ \\
\hline Cash-richness & $\begin{array}{c}-0.0204 * * * \\
(0.0018)\end{array}$ & $\begin{array}{c}-0.0195 * * * \\
(0.0015)\end{array}$ & $\begin{array}{c}-0.0178 * * * \\
(0.0016)\end{array}$ & $\begin{array}{c}-0.0197 * * * \\
(0.0013)\end{array}$ & $\begin{array}{c}-0.0196^{* * * *} \\
(0.0016)\end{array}$ & $\begin{array}{c}-0.0167 * * * \\
(0.0018)\end{array}$ & $\begin{array}{c}-0.0173 * * * \\
(0.0018)\end{array}$ & & $\begin{array}{c}-0.0259 * * * \\
(0.0094)\end{array}$ & $\begin{array}{c}-0.0264 * * * \\
(0.0015)\end{array}$ \\
\hline Tangibility & $\begin{array}{c}0.1676^{* * * *} \\
(0.0055)\end{array}$ & $\begin{array}{c}0.0908^{* * * *} \\
(0.0043)\end{array}$ & $\begin{array}{c}0.1638^{* * *} \\
(0.0048)\end{array}$ & $\begin{array}{c}0.1543 * * * \\
(0.0033)\end{array}$ & $\begin{array}{c}0.1157 * * * \\
(0.0148)\end{array}$ & $\begin{array}{c}0.1490^{* * *} \\
(0.0053)\end{array}$ & $\begin{array}{c}0.1440^{* * * *} \\
(0.0054)\end{array}$ & & $\begin{array}{l}0.0946 * * * \\
(0.0089)\end{array}$ & $\begin{array}{c}0.0102 * * * \\
(0.0034)\end{array}$ \\
\hline Liquidity & $\begin{array}{l}-0.0002^{*} \\
(0.0001)\end{array}$ & $\begin{array}{l}-0.0000 \\
(0.0001)\end{array}$ & $\begin{array}{c}-0.0003 * * * \\
(0.0001)\end{array}$ & $\begin{array}{c}-0.0002 * * * \\
(0.0001)\end{array}$ & $\begin{array}{c}0.0000 \\
(0.0001)\end{array}$ & $\begin{array}{c}-0.0004 * * * \\
(0.0001)\end{array}$ & $\begin{array}{c}-0.0004 * * * \\
(0.0001)\end{array}$ & & $\begin{array}{c}-0.0021 * * * \\
(0.0003)\end{array}$ & $\begin{array}{c}-0.0012 * * * \\
(0.0001)\end{array}$ \\
\hline Trade Credit & $\begin{array}{l}-0.1172 * * * \\
(0.0037)\end{array}$ & $\begin{array}{c}-0.0184 * * * \\
(0.0030)\end{array}$ & $\begin{array}{c}-0.1155^{* * *} \\
(0.0032)\end{array}$ & $\begin{array}{c}-0.1256^{* * * *} \\
(0.0024)\end{array}$ & $\begin{array}{c}-0.1291 * * * \\
(0.0041)\end{array}$ & $\begin{array}{c}-0.1185^{* * *} \\
(0.0036)\end{array}$ & $\begin{array}{c}-0.1198 * * * \\
(0.0037)\end{array}$ & & $\begin{array}{c}0.0135 \\
(0.0329)\end{array}$ & $\begin{array}{c}-0.0148 * * \\
(0.0071)\end{array}$ \\
\hline Growth Opportunity & $\begin{array}{c}0.0741 * * * \\
(0.0121)\end{array}$ & $\begin{array}{c}0.0783 * * * \\
(0.0129)\end{array}$ & $\begin{array}{c}0.0481 * * * \\
(0.0121)\end{array}$ & $\begin{array}{c}0.0693 * * * \\
(0.0072)\end{array}$ & $\begin{array}{c}0.0376 * * \\
(0.0148)\end{array}$ & $\begin{array}{c}0.0470 * * * \\
(0.0142)\end{array}$ & $\begin{array}{c}0.0527 * * * \\
(0.0144)\end{array}$ & & $\begin{array}{c}-0.0305^{*} \\
(0.0166)\end{array}$ & $\begin{array}{c}0.0243 * * * \\
(0.0048)\end{array}$ \\
\hline GDP growth rate & $\begin{array}{c}0.0010 * * * \\
(0.0001)\end{array}$ & $\begin{array}{c}0.0011 * * * \\
(0.0001)\end{array}$ & $\begin{array}{l}0.0002^{*} \\
(0.0001)\end{array}$ & $\begin{array}{c}-0.0010^{* * * *} \\
(0.0004)\end{array}$ & $\begin{array}{c}-0.0004 \\
(0.0004)\end{array}$ & $\begin{array}{c}0.0002 * * \\
(0.0001)\end{array}$ & $\begin{array}{c}-0.0008 * * * \\
(0.0001)\end{array}$ & & $\begin{array}{c}-0.0004 \\
(0.0013)\end{array}$ & $\begin{array}{l}-0.0005 \\
(0.0006)\end{array}$ \\
\hline Bank importance & $\begin{array}{c}0.0005^{* * *} * \\
(0.0000)\end{array}$ & $\begin{array}{c}0.0005^{* * * *} \\
(0.0000)\end{array}$ & $\begin{array}{c}0.0005 * * * \\
(0.0000)\end{array}$ & $\begin{array}{c}0.0002 * * * \\
(0.0001)\end{array}$ & $\begin{array}{c}0.0002 * * * \\
(0.0001)\end{array}$ & $\begin{array}{c}0.0005^{* * *} * \\
(0.0000)\end{array}$ & $\begin{array}{c}0.0000 \\
(0.0000)\end{array}$ & & $\begin{array}{l}-0.0001 \\
(0.0008)\end{array}$ & $\begin{array}{c}0.0002 * * * \\
(0.0000)\end{array}$ \\
\hline Bank activity & $\begin{array}{c}-0.0057^{* *} \\
(0.0024)\end{array}$ & $\begin{array}{l}-0.0039 \\
(0.0026)\end{array}$ & $\begin{array}{l}-0.0024 \\
(0.0021)\end{array}$ & $\begin{array}{c}-0.0097 * * * \\
(0.0020)\end{array}$ & $\begin{array}{c}-0.0096 * * * \\
(0.0021)\end{array}$ & $\begin{array}{l}-0.0001 \\
(0.0027)\end{array}$ & $\begin{array}{l}-0.0013 \\
(0.0024)\end{array}$ & & $\begin{array}{l}0.0078^{*} \\
(0.0045)\end{array}$ & $\begin{array}{c}-0.1195 * * * \\
(0.0133)\end{array}$ \\
\hline Bank DEA efficiency & $\begin{array}{c}0.0176^{* * *} * \\
(0.0033) \\
\end{array}$ & $\begin{array}{c}0.0486^{* * * *} \\
(0.0041) \\
\end{array}$ & $\begin{array}{c}0.0622 * * * \\
(0.0097)\end{array}$ & $\begin{array}{c}0.0097 * * * \\
(0.0031)\end{array}$ & $\begin{array}{c}0.0133^{* * * *} \\
(0.0030)\end{array}$ & $\begin{array}{c}0.0446 * * * \\
(0.0102) \\
\end{array}$ & $\begin{array}{c}0.0033 \\
(0.0036) \\
\end{array}$ & & $\begin{array}{l}0.0723^{*} \\
(0.0440) \\
\end{array}$ & $\begin{array}{c}0.0211^{* *} \\
(0.0104) \\
\end{array}$ \\
\hline Observations & 328,491 & 322,688 & 287,281 & 302,272 & 319,662 & 233,806 & 229,907 & Obs. & 268,379 & 343,548 \\
\hline Groups & 64,497 & 64,358 & 63,169 & 63,053 & 63,626 & 54,247 & 53,989 & Groups & 57,455 & 63,703 \\
\hline Estimator & $\mathrm{FE}$ & $\mathrm{FE}$ & FE 2SLS IV & FE 2SLS IV & FE 2SLS IV & FE 2SLS IV & FE 2SLS IV & Estimator & 2S D-GMM & 2S S-GMM \\
\hline $\mathrm{IV}(\mathrm{s})$ for $\mathrm{BMP}$ & N/A & N/A & lag $(1,2)$. Lerner & $\operatorname{lag}(1)$. ROAA & $\operatorname{lag}(1) \cdot \operatorname{adj-NIM}$ & $\operatorname{lag}(1) . \mathrm{T} 1$ ratio & all (9-12) & $\mathrm{P}$ AR(1) & 0.000 & 0.000 \\
\hline P (K-P rk LM) & N/A & N/A & 0.0000 & 0.0000 & 0.0000 & 0.0000 & 0.0000 & $\mathrm{P}-\mathrm{AR}(2)$ & 0.017 & 0.090 \\
\hline WIT Wald F-stats & N/A & N/A & 9243.25 & 869.04 & 15.15 & 1225.24 & 5323.24 & $\mathrm{P}-(\mathrm{AR} 3)$ & 0.578 & 0.345 \\
\hline $\begin{array}{r}\text { Hansen } \mathbf{J} \text { stats } \\
\mathrm{R} 2\end{array}$ & N/A & N/A & 0.2934 & 0.0471 & 0.1253 & 0.0000 & 0.1977 & P-Sargan & 0.111 & 0.113 \\
\hline $\mathrm{R} 2$ & $82.01 \%$ & $81.51 \%$ & $4.22 \%$ (centred) & $4.44 \%$ (centred) & $4.70 \%$ (centred) & $4.06 \%$ (centred) & $3.98 \%$ (centred) & P-Hansen & 0.495 & 0.715 \\
\hline
\end{tabular}

$*, * *$ and $* * *$ respectively represents significance at $10 \%, 5 \%$ and $1 \%$ level. Models 10 and 11 adopt fixed-effects estimator (FE). Models 12 to 16 are estimated by fixed-effects two-stage least squares estimator. The standard errors of all FE and FE 2SLS IV models are clustered at firm-level. The last two columns (Models 17 and 18 ) are dynamic panel data models estimated by two-stage "differencing" GMM estimator (Arellano and Bond, 1991) and two-step "System" GMM estimator (Arellano and Bover, 1995; Blundell and Bond, 1998). We present several econometrics diagnostic tests designed for endogeneity correction models, including p-values of Underidentification test (Kleibergen-Paap rk LM statistics, or in the table P (K-P rk LM)), F-statistics of Weak identification test (Kleibergen-Paap rk Wald F statistics, or in the table WIT Wald F-stats), p-values of Overidentification test of all instruments, known as Hansen and Sargan tests, and p-values of $1^{\text {st }}, 2^{\text {nd }}$ and $3^{\text {rd }}$ order serial correlation tests. Other notes are same as above (Table 6). 


\section{Table 9: Heterogeneity tests}

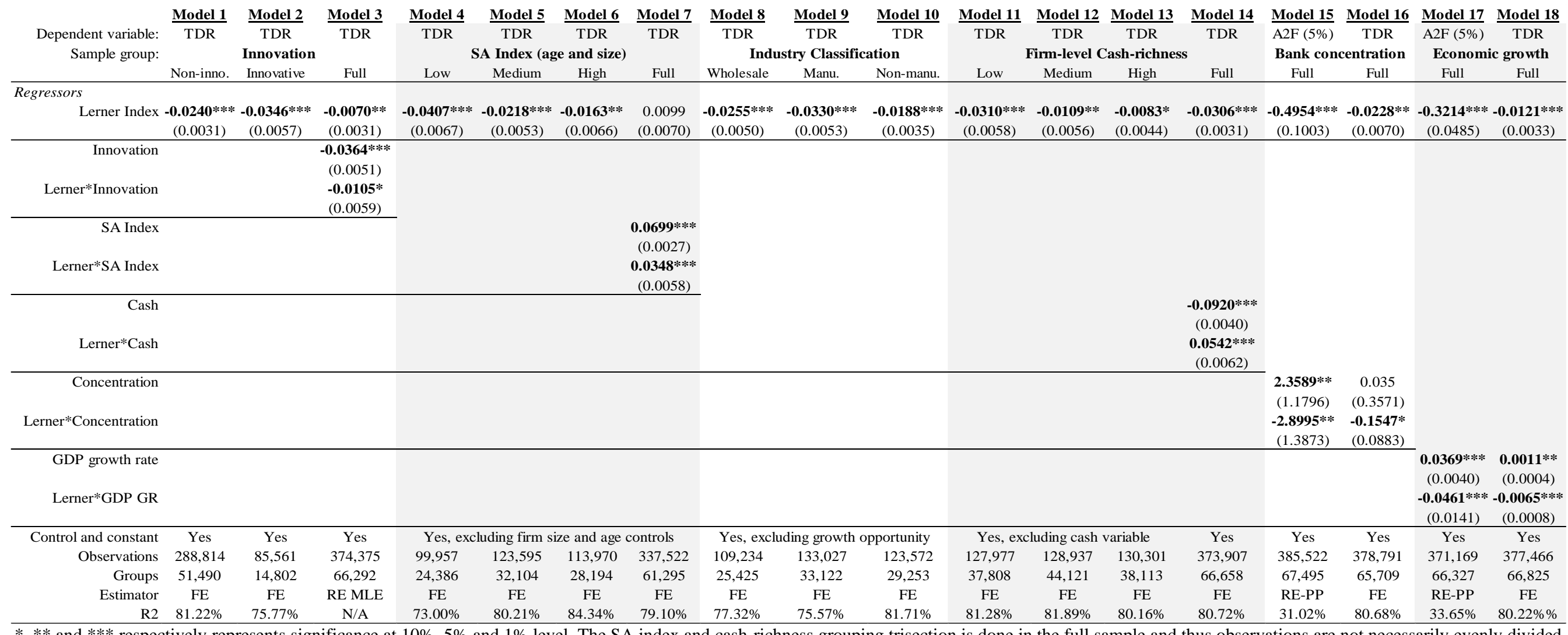

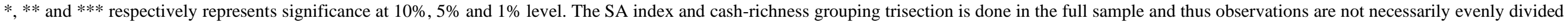

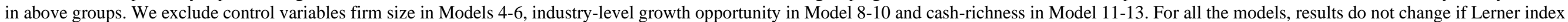
is replaced by lending market Lerner index. Other notes are same as above (Table 6). 
Table 10: Additional tests

\begin{tabular}{|c|c|c|c|c|c|}
\hline Dependent variable: & $\begin{array}{l}\text { Model 1 } \\
\begin{array}{c}\text { Short-term debt } \\
\text { to assets }\end{array}\end{array}$ & $\begin{array}{l}\text { Model 2 } \\
\begin{array}{l}\text { Long-term debt } \\
\text { to assets }\end{array}\end{array}$ & $\begin{array}{l}\frac{\text { Model 3 }}{\text { Short-term debt }} \\
\text { to total debt } \\
\text { (STDTD) }\end{array}$ & $\begin{array}{l}\text { Model 4 } \\
\text { STDTD } \\
\text { industry } \\
\text { difference }\end{array}$ & $\begin{array}{c}\frac{\text { Model 5 }}{\text { STDTD }} \\
\text { industry } \\
\text { difference WA } \\
\text { by assets }\end{array}$ \\
\hline \multicolumn{6}{|l|}{ Main regressors } \\
\hline Lerner Index & $\begin{array}{c}\mathbf{- 0 . 0 1 4 5} * * * \\
(0.0028)\end{array}$ & $\begin{array}{c}\mathbf{- 0 . 0 1 7 2} * * * \\
(0.0030)\end{array}$ & $\begin{array}{c}\mathbf{- 0 . 0 1 6 2} * * \\
(0.0078) \\
\end{array}$ & $\begin{array}{c}\mathbf{- 0 . 0 1 5 9} * * \\
(0.0075)\end{array}$ & $\begin{array}{c}\mathbf{- 0 . 0 1 6 3 * *} \\
(0.0076) \\
\end{array}$ \\
\hline \multicolumn{6}{|l|}{ Control variables } \\
\hline Firm size & $\begin{array}{c}0.0207 * * * \\
(0.0010)\end{array}$ & $\begin{array}{c}0.0245 * * * \\
(0.0013)\end{array}$ & $\begin{array}{c}-0.0108 * * * \\
(0.0026)\end{array}$ & $\begin{array}{c}-0.0165 * * * \\
(0.0025)\end{array}$ & $\begin{array}{c}-0.0080 * * * \\
(0.0025)\end{array}$ \\
\hline Cash-richness & $\begin{array}{c}-0.0140 * * * \\
(0.0012)\end{array}$ & $\begin{array}{c}-0.0120 * * * \\
(0.0012)\end{array}$ & $\begin{array}{c}-0.0289 * * * \\
(0.0045)\end{array}$ & $\begin{array}{c}-0.0221 * * * \\
(0.0045)\end{array}$ & $\begin{array}{c}-0.0290 * * * \\
(0.0044)\end{array}$ \\
\hline Tangibility & $\begin{array}{l}-0.0033 \\
(0.0032)\end{array}$ & $\begin{array}{c}0.1498 * * * \\
(0.0048)\end{array}$ & $\begin{array}{c}-0.2447 * * * \\
(0.0081)\end{array}$ & $\begin{array}{c}-0.2368 * * * \\
(0.0077)\end{array}$ & $\begin{array}{c}-0.2341 * * * \\
(0.0077)\end{array}$ \\
\hline Liquidity & $\begin{array}{c}-0.0007 * * * \\
(0.0001)\end{array}$ & $\begin{array}{c}0.0005 * * * \\
(0.0001)\end{array}$ & $\begin{array}{c}-0.0015 * * * \\
(0.0002)\end{array}$ & $\begin{array}{c}-0.0014 * * * \\
(0.0002)\end{array}$ & $\begin{array}{c}-0.0015 * * * \\
(0.0002)\end{array}$ \\
\hline Trade Credit & $\begin{array}{c}-0.0811 * * * \\
(0.0026)\end{array}$ & $\begin{array}{c}-0.0247 * * * \\
(0.0025)\end{array}$ & $\begin{array}{c}-0.0590 * * * \\
(0.0075)\end{array}$ & $\begin{array}{c}-0.0819 * * * \\
(0.0073)\end{array}$ & $\begin{array}{c}-0.0602 * * * \\
(0.0074)\end{array}$ \\
\hline Growth Opportunity & $\begin{array}{l}-0.0004 \\
(0.0074)\end{array}$ & $\begin{array}{c}0.0865 * * * \\
(0.0104)\end{array}$ & $\begin{array}{c}-0.1530 * * * \\
(0.0199)\end{array}$ & $\begin{array}{c}-0.0009 * * * \\
(0.0002)\end{array}$ & $\begin{array}{c}-0.0016 * * * \\
(0.0002)\end{array}$ \\
\hline GDP growth rate & $\begin{array}{c}0.0002 * * * \\
(0.0001)\end{array}$ & $\begin{array}{c}0.0005 * * * \\
(0.0001)\end{array}$ & $\begin{array}{c}-0.0015^{* * *} * \\
(0.0002)\end{array}$ & $\begin{array}{c}-0.0002 * * * \\
(0.0000)\end{array}$ & $\begin{array}{c}-0.0003 * * * \\
(0.0000)\end{array}$ \\
\hline Bank importance & $\begin{array}{c}0.0001 * * * \\
(0.0000)\end{array}$ & $\begin{array}{c}0.0004 * * * \\
(0.0000)\end{array}$ & $\begin{array}{c}-0.0003 * * * \\
(0.0001)\end{array}$ & $\begin{array}{c}0.0038 \\
(0.0053)\end{array}$ & $\begin{array}{c}0.0058 \\
(0.0055)\end{array}$ \\
\hline Bank activity & $\begin{array}{l}-0.0019 \\
(0.0018)\end{array}$ & $\begin{array}{c}-0.0055^{* * *} * \\
(0.0021)\end{array}$ & $\begin{array}{c}0.0085 \\
(0.0056)\end{array}$ & $\begin{array}{c}0.0092 \\
(0.0086)\end{array}$ & $\begin{array}{c}0.0117 \\
(0.0088)\end{array}$ \\
\hline Bank DEA efficiency & $\begin{array}{c}0.0182 * * * \\
(0.0030) \\
\end{array}$ & $\begin{array}{c}0.0152 * * * \\
(0.0033) \\
\end{array}$ & $\begin{array}{c}0.0163 \\
(0.0140) \\
\end{array}$ & $\begin{array}{c}0.4168 * * * \\
(0.0437)\end{array}$ & $\begin{array}{c}0.2738 * * * \\
(0.0438) \\
\end{array}$ \\
\hline Observations & 356,825 & 356,825 & 308,561 & 298,657 & 313,981 \\
\hline Groups & 63,787 & 63,787 & 59,462 & 58,024 & 60,418 \\
\hline Estimator & $\mathrm{FE}$ & $\mathrm{FE}$ & FE & FE & FE \\
\hline $\mathrm{R}^{2}$ & $69.92 \%$ & $77.21 \%$ & $63.64 \%$ & $61.83 \%$ & $62.40 \%$ \\
\hline
\end{tabular}

*,** and $* * *$ respectively represents significance at $10 \%, 5 \%$ and $1 \%$ level. WA is short for weighted-averaged. Other notes are same as above (Table 6). 